\title{
Numerical modeling of gas hydrate emplacements in oceanic sediments
}

\author{
Philippe Schnürle ${ }^{a, *}$, Char-Shine Liu ${ }^{b}$ \\ ${ }^{a}$ Department of Marine Geosciences, Ifremer, 29280 Brest, France \\ ${ }^{\mathrm{b}}$ Institute of Oceanography, National Taiwan University, Taipei, Taiwan, ROC \\ *: Corresponding author : Philippe Schnürle, Fax: +2 982245 49., email address : philippe.schnurle@ifremer.fr
}

\begin{abstract}
:
We have implemented a 2-dimensional numerical model for simulating gas hydrate and free gas accumulation in marine sediments. The starting equations are those of the conservation of the transport of momentum, energy, and mass, as well as those of the thermodynamics of methane hydrate stability and methane solubility in the pore-fluid. These constitutive equations are then integrated into a finite element in space, finite-difference in time scheme. We are then able to examine the formation and distribution of methane hydrate and free gas in a simple geologic framework, with respect to the geothermal heat flow, fluid flow, the methane in-situ production and basal flux. Three simulations are performed, leading to the build up of hydrate emplacements largely linear through time. Models act primarily as free gas accumulators and are relatively inefficient with respect to hydrate emplacements: $26 \mathrm{i} 33 \%$ of formed methane are converted to hydrate. Seepage of methane across the sea-floor is negligible for fluid flow below $2.10^{i 11} \mathrm{~kg} / \mathrm{m}^{2} / \mathrm{s}$. At $5.62510^{i 11} \mathrm{~kg} / \mathrm{m}^{2} / \mathrm{s}$ however, $9.7 \%$ of the formed methane seeps out of the model. Moreover, along strike variation arising in the 2dimensional model are outlined. In the absence of focused flow, the thermodynamics of hydrate accumulation are primarily one-dimensional. However, changes in free methane compressibility (density) and methane solubility (the intrinsic dissolved methane flux) subtlety impact on the formation of a free gas zone and the distribution of the hydrate emplacements in our 2-dimensional simulations.
\end{abstract}

\section{Highlights}

$32 \mathrm{D}$ finite element methane hydrate emplacement simulator. $32 \mathrm{D}$ structurally-related methane density and solubility variations. 3 Free gas and hydrate saturation for weak/high pore-water flux and deep/shallow seabed.

Keywords : Gas hydrates ; Methane solubility ; Finite-elements ; Simulation

\section{Introduction}

Clathrate compounds were discovered in the early 1800s by Humphrey Davy and Michael Faraday while experimenting with chlorine-water mixtures: as the mixtures cooled, a solid 
material formed at temperatures above the normal freezing point of water. Low-molecularweight gases (methane for instance) and water combine to form crystalline clathrate hydrates of gas or "gas hydrates" at high pressures, low temperatures, within specific gas concentrations, and water activity (Duan et al., 1992). In the late 1960s, "solid natural gas" or methane hydrate was observed as a naturally-occurring constituent of subsurface sediments in Messoyahka gas field of the Western Siberia basin. Then in 1974, Soviet scientists recovered large hydrate nodules from the floor of the Black Sea: thermodynamically favorable conditions to the formation of methane hydrate exits beneath seafloor sediments (the gas hydrate stability zone) down to depth where the geothermal gradient exceeds the three-phase equilibrium (the base of the GHSZ). Submarine gas hydrates are often found with a free gas layer below the BGHSZ. Degradation of reactive organic matter, through bacterial methanogenesis and, in some cases, thermogenesis produce copious amounts of methane in deep water continental margin sediment, either within or transported into the GHSZ. Hence, oceanic gas hydrates probably comprise the largest pool of organic carbon in the shallow geosphere (Kvenvolden, 1988).

Understanding the factors that control the emplacement of gas hydrates in submarine sediments appears critical when examining natural gas hydrate as a possible energy resource, a submarine geohazard, or an agent of climate change. A decade ago, conceptual models for the kinetics of gas hydrate formation at the pore scale (e.g. Clennell et al., 1999; Henry et al., 1999), together with the basic equations of state for natural gas hydrate emplacements, steadystate and 1-dimentional at first, where solidly established (e.g. Rumpel and Buffet, 1997; Xu and Ruppel, 1999; Davie and Buffet, 2003; Gering, 2003). Since, kinetic models in porous media (e.g. Genov et al. 2004; Sun and Mohanty, 2006), as well as 2 and 3 dimensional models at geological scale (e.g. Sun et al., 2005; He et al., 2006; Moridis and Sloan, 2007; Garg et al., 2008) further matured. Often, these studies focus on determining the geological conditions necessary to match observed in-situ down-hole measurements, such as chlorinity, temperature, or gas hydrates concentrations, or the formation of carbonates, or near-surface methane depletion from the anaerobic methane oxidation zone in piston cores. Other models emphasize on future exploitation of gas hydrate, reservoir depletion during gas production (e.g. Moridis et al., 2007; Moridis et al., 2009), and coupling with sediment mechanics (Kimoto et al., 2007). Today, hydrate models remain relevant and fruitful in distinguishing critical thermodynamic and physical factors for natural hydrate emplacement at field scale, and set the conceptual framework for geologists, geochemists, and geophysicists during 
natural gas hydrate exploration in sub-marine geological structures (e.g. Riedel et al., 2006; Tréhu et al., 2006).

\section{Numerical Model}

\subsection{Equations of State}

Gas hydrate in marine sediment form under conditions of relative high pressure and low temperature, when the gas concentration exceeds those that can be held in solution. Methane solubility at high-pressure conditions have received considerable attention, through experimental (e.g. Chapoy et al., 2004), and modeling studies (Tishchenko et al., 2005; Duan and Mao, 2006; Sun and Duan, 2007): the solubility presents a temperature-dependant quasiexponential decay from the solubility at the methane hydrate phase boundary in the hydrate stability domain (Fig. 1). Concentration of salt ions $(\mathrm{Na}$ and $\mathrm{Cl}$ ) also impact on the decay of solubility in the stability zone. Hence, Tishchenko et al. (2005), using the rigorous ion interaction method of Pitzer, propose empirical algorithms for hydrate dissociation pressures and methane concentrations, in seawater and pore water equilibrated with methane hydrate, as functions of chlorinity $\mathrm{Cl}$ (in ppt), temperature and hydrostatic pressure. The pore-water dissociation pressures $\mathrm{P}_{\mathrm{w}}$ dis for a temperature range of $273-293 \mathrm{~K}$ and chlorinity of 0-70 obeys:

$\ln \left(\mathrm{P}_{\mathrm{w}}{ }^{\mathrm{dis}} / \mathrm{MPa}\right)=1.689269210^{3}-0.15162984 . \mathrm{T}+5.6091248210^{4} / \mathrm{T}+2.7206750610^{2} \ln (\mathrm{T})+$ $\mathrm{Cl}\left[2.0662129810^{4}+14.18127 \mathrm{~T}-8.341706610^{3} \mathrm{~T}^{2}-3.7875751910^{5} / \mathrm{T}\right.$

$\left.+4.0154441710^{3} \cdot \ln (\mathrm{T})\right]+\mathrm{Cl}^{2}\left[6.0401804510^{2}+0.420253434 \mathrm{~T}+2.50154810^{4} \mathrm{~T}^{2}-\right.$ $\left.1.0974533510^{4} / \mathrm{T}-1.1764096610^{2} \ln (\mathrm{T})\right]$

The solubility of methane $\mathrm{C}_{\mathrm{CH} 4}$ at the dissociation pressures $\mathrm{P}_{\mathrm{w}}{ }^{\text {dis }}$ up to $50 \mathrm{Mpa}$ and in the same temperature/chlorinity range obeys:

$\ln \left[\mathrm{C}_{\mathrm{CH} 4} / \mathrm{mol} \mathrm{kg}^{-1}\right]$ at $\left(\mathrm{P}_{\mathrm{w}}=\mathrm{P}_{\mathrm{w}}{ }^{\text {dis }}\right)=-2.5435085810^{5}-1.63068066210^{2} \mathrm{~T}+9.025548310^{-2} \cdot \mathrm{T}^{2}$ $+4.8659951210^{6} / \mathrm{T}+4.8902074710^{4} \ln (\mathrm{T})+\mathrm{Cl}\left[-1.1011746410^{3}-0.72234127 \mathrm{~T}+4.07255\right.$ $\left.10^{-4} \mathrm{~T}^{2}+2.0742501910^{4} / \mathrm{T}+2.1250380110^{2} \ln (\mathrm{T})\right]$

The solubility of methane hydrate $\mathrm{C}_{\mathrm{CH} 4}^{\mathrm{h}}$ at pressure $\mathrm{P}_{\mathrm{w}}$ below $\mathrm{P}_{\mathrm{w}}$ dis obeys:

$\ln \left[\mathrm{C}^{\mathrm{h}} \mathrm{CH}_{4} / \mathrm{mol} \mathrm{kg}^{-1}\right]\left(\mathrm{P}_{\mathrm{w}}\right)=\ln \left[\mathrm{C}_{\mathrm{CH} 4} / \mathrm{mol} \mathrm{kg}^{-1}\right]$ at $\left(\mathrm{P}_{\mathrm{w}}=\mathrm{P}_{\mathrm{w}}{ }^{\text {dis }}\right)+\left[5.0459710^{-2}+1.3809510^{-3} \mathrm{Cl}-\right.$ $\left.\left(3.9023610^{-4}+9.91710^{-6} \mathrm{Cl}\right) \mathrm{T}+\left(7.0615410^{-7}+1.7844110^{-8} \mathrm{Cl}\right) \mathrm{T}^{2}\right]\left(\mathrm{P}_{\mathrm{w}}-\mathrm{P}_{\mathrm{w}}{ }^{\text {dis }}\right)+[7.57285$ $\left.10^{-5}-3.4481110^{-8} . \mathrm{Cl}-4.7267110^{-10} \mathrm{Cl}^{2}+\left(-1.9620710^{-7}+1.2057910^{-10} \mathrm{Cl}\right) \mathrm{T}\right]\left(\mathrm{P}_{\mathrm{w}}-\mathrm{P}_{\mathrm{w}}{ }^{\text {dis }}\right)^{2}$ 
The accuracy of these functions to predict the behaviour of methane in marine sediments is arguable but give a good approximation in order to demonstrate the significance and magnitude of this effect (Tishchenko et al., 2005).

A thermodynamic model for calculating the solubility of methane gas phase $\mathrm{C}_{\mathrm{CH} 4}^{\mathrm{g}}$ accurate to about $6 \%$ at pressure $\mathrm{P}_{\mathrm{w}}$ below $\mathrm{P}_{\mathrm{w}}$ dis from 273 to $523{ }^{\circ} \mathrm{K}$ and 1 to $200 \mathrm{MPa}$ is proposed by Duan and Mao (2006) and is made by them available on-line (http://www.geochemmodel.org/). Instead of solving the thermodynamic equilibrium at every node for every time step of our calculations, we interpolate $\mathrm{C}_{\mathrm{CH} 4}^{\mathrm{g}}$ from a table of 201 pre-computed values 273 to $393{ }^{\circ} \mathrm{K}$ and 1 to $100 \mathrm{MPa}$ after Duan and Mao (2006): the minor loss in accuracy is warrant by the decrease in computational resource.

The pre-computed 2-phase and independent 3-phase solubilities are slightly discontinuous at the GH phase boundary: in the temperature range of 273 to $293{ }^{\circ} \mathrm{K}$ and pressure range of 5 to $40 \mathrm{MPa}$, we reduce these discrepancies of solubility to less than $1 \%$ by increasing salt ions content in the 2-phase domain to $3.98 \mathrm{wt} \%$ (and decreasing $\mathrm{S}$ to 32 ) to match $\mathrm{Cl}=19 \mathrm{ppt}$ in the 3-phase domain (Fig 1b). Finally, continuity near the phase boundary is enforced during the 2-phase solubility bilinear-interpolation by substituting the 2-phase solubility in the hydrate stability domain by the 3-phase solubility at the phase boundary.

Then, simulating the mechanisms leading to natural gas hydrate emplacement in geological environments requires the modeling of the temperature, the pressure, the chemical reactions, and the convective/diffusive flow of the reactive species. Two chemical components ( $\mathrm{i}=$ =methane, water), and 3 phases $(\mathrm{j}=$ aqueous, gas and solid) are considered, resulting in 6 unknown masses per unit volume $\mathrm{M}_{\mathrm{i}}^{\mathrm{j}}$. In this study, we take into account the distribution of dissolved methane $\left(\mathrm{M}_{\mathrm{d}}=\mathrm{M}_{\mathrm{m}}{ }^{\mathrm{a}}\right)$, methane gas $\left(\mathrm{M}_{\mathrm{g}}=\mathrm{M}_{\mathrm{m}}{ }^{\mathrm{g}}\right)$, methane hydrate $\left(\mathrm{M}_{\mathrm{h}}=\mathrm{M}_{\mathrm{m}}{ }^{\mathrm{s}}\right)$, and water $\left(\mathrm{S}_{\mathrm{w}}=\mathrm{M}_{\mathrm{w}}{ }^{\mathrm{a}}\right)$, while water vapor $\left(\mathrm{M}_{\mathrm{v}}=\mathrm{M}_{\mathrm{w}}{ }^{\mathrm{g}}\right)$, and ice $\left(\mathrm{M}_{\mathrm{i}}=\mathrm{M}_{\mathrm{w}}{ }^{\mathrm{s}}\right)$ are neglected. The vapor pressure for water is quite small $(<0.02 \mathrm{MPa})$ at temperatures less than $60{ }^{\circ} \mathrm{C}$; it is therefore reasonable to assume that the gas phase contains only a negligible amount of water vapor (Garg et al., 2008). Through time, the concentrations of these species evolve due to transport in the porous medium: the fluid flux $\left(\mathrm{U}_{\mathrm{f}}\right)$, and gas flux $\left(\mathrm{U}_{\mathrm{g}}\right)$ are responsible for the convection of porewater, dissolved methane, and free gas; Chemical species are also subject to diffusion. Thus the starting equations are those of the conservation of mass, energy, and the transport of momentum, along with equilibrium and kinetics relations of hydrate formation. In this study, we extend the 1-dimentional equations given by Sun et al. (2005), Esmaeilzadeh et al. (2008) and Garg et al. (2008) to the second dimension. 


\subsection{Mass Balance}

The mass balance for hydrate, pore-water and total methane gas in a medium of porosity $\Phi$ are:

$$
\partial \Phi \mathrm{M}_{\mathrm{h}} / \partial \mathrm{t}=\dot{\mathrm{g}}_{\mathrm{h}},
$$

where $\dot{\mathrm{g}}_{\mathrm{h}}$ is the local mass rate of hydrate formation/dissociation, and assuming that hydrate phase and the sediment matrix are fixed, i.e. $\mathrm{U}_{\mathrm{h}}=0$;

$\partial \Phi \mathrm{M}_{\mathrm{w}} / \partial \mathrm{t}+\nabla\left(\mathrm{U}_{\mathrm{w}} \mathrm{M}_{\mathrm{w}}\right)=\dot{\mathrm{g}}_{\mathrm{w}}$,

$\partial \Phi\left(\mathrm{M}_{\mathrm{h}}+\mathrm{M}_{\mathrm{g}}+\mathrm{M}_{\mathrm{d}}\right) / \partial \mathrm{t}+\nabla\left(\mathrm{U}_{\mathrm{g}} \mathrm{M}_{\mathrm{g}}\right)+\nabla\left(\mathrm{U}_{\mathrm{w}} \mathrm{M}_{\mathrm{d}}\right)=\nabla\left[\Phi \mathrm{D}_{\mathrm{m}} \nabla\left(\mathrm{M}_{\mathrm{g}}+\mathrm{M}_{\mathrm{d}}\right)\right]+\dot{\mathrm{g}}_{\mathrm{g}}+\mathrm{F}_{\mathrm{g}}$,

where $F_{g}$ is the gas generation term which account for an internal sources (the in-situ biogenic methane generation).

Although self-diffusion coefficients of methane gas in pure component have been estimated by NMR experiments as 43 to $7510^{-9} \mathrm{~m}^{2} / \mathrm{s}$ at 303 and $50 \mathrm{Mpa}$ to $333{ }^{\circ} \mathrm{K}$ and 30 to Mpa (Helbæket al., 1996), the effective diffusion of a gas which permeates a porous medium further depends on the ratio of the mean free path of the gas to the pore dimensions, the neighboring pore structure, and the nature of the gas-solid interactions, and counter-diffusion in capillaries. Diffusivity of dissolved methane in water has been estimated to range from 1.84 to $2.0910^{-9} \mathrm{~m}^{2} / \mathrm{s}$ at $15.6413 \mathrm{MPa}$ in a PVT cell and gas-autoclave at $30.088^{\circ} \mathrm{C}$ (Sachs, 1998). In the absence of more data, we assume is this study an equal methane isothermal porositydependant diffusion coefficient in both the gas and dissolved phase, and no diffusion of the hydrate phase:

$\mathrm{D}_{\mathrm{d}}{ }^{\mathrm{g}}=\mathrm{D}_{\mathrm{g}}{ }^{\mathrm{g}}=\mathrm{D}_{\mathrm{m}} /[1+\mathrm{n}(1-\Phi)]$,

with $\mathrm{D}_{\mathrm{m}}=10^{-9} \mathrm{~m}^{2} / \mathrm{s}$ and $\mathrm{n}=3$ for muddy sediment (Iverson and Jorgensen, 1993 ; Lin et al., 2006).

At geological times, hydrate formation/dissociation is not rate limited (e.g. Kim et al, 1987; Kowalsky and Moridis, 2007), and stoichiometry relates local mass rates of hydrate, water and gas, to the hydrate number $\mathrm{N}_{\mathrm{h}}$ and the molecular weights of water $\mathrm{m}_{\mathrm{w}}=18.01524 \mathrm{~g} / \mathrm{mol}$ and gas $\mathrm{m}_{\mathrm{g}}=16.0425 \mathrm{~g} / \mathrm{mol}$ :

$\dot{\mathrm{g}}_{\mathrm{w}}=\dot{\mathrm{g}}_{\mathrm{h}} \mathrm{N}_{\mathrm{h}} \mathrm{m}_{\mathrm{g}} /\left(\mathrm{m}_{\mathrm{g}}+\mathrm{N}_{\mathrm{h}} \mathrm{m}_{\mathrm{w}}\right)$, and $\dot{\mathrm{g}}_{\mathrm{g}}=\dot{\mathrm{g}}_{\mathrm{h}} \mathrm{m}_{\mathrm{g}} /\left(\mathrm{m}_{\mathrm{g}}+\mathrm{N}_{\mathrm{h}} \mathrm{m}_{\mathrm{w}}\right)$,

The masses $M_{i}$ relate to pore-space saturation $S_{i}$ and densities $\rho_{i}$ : $M_{i}=\rho_{i} S_{i}$,

with $\mathrm{S}_{\mathrm{h}}+\mathrm{S}_{\mathrm{w}}+\mathrm{S}_{\mathrm{g}}=1$;

\subsection{Momentum Balance}


Our model assumes that pore-water flux $\left(U_{w}\right)$, and gas flux $\left(U_{g}\right)$ obey Darcy's law for multiphase flow. For the pore-water phase:

$\mathrm{U}_{\mathrm{w}}=-\mathrm{K} \mathrm{k}_{\mathrm{rw}} \mathrm{k}_{\mathrm{rs}} / \mu_{\mathrm{w}}\left(\nabla \mathrm{P}_{\mathrm{w}}+\rho_{\mathrm{w}} \mathrm{g}\right)$, where the pore-water viscosity $\mu_{\mathrm{w}}=1420 \mu \mathrm{Pas}$ is constant;

The porous medium absolute permeability $\mathrm{K}$ may vary considerably from geological provinces and with lithology. $\mathrm{K}$ is modeled as a power law function of porosity:

$\mathrm{K}(\Phi)=\mathrm{K}_{\mathrm{o}}\left(\Phi / \Phi_{\mathrm{o}}\right)^{\mathrm{mk}}$, where $\mathrm{m}_{\mathrm{k}}=2.5, \mathrm{~K}_{\mathrm{o}}=2.510^{-15} \mathrm{~m}^{2}$ and $\Phi_{\mathrm{o}}$ is the reference porosity at seafloor.

Enhanced chemical effects exhibited by clay minerals increase values of $m_{k}$ up to 8 (Smith, 1971) away from the normal values of 2-3 associated with the Carman-Kozeny law for granular materials (Fowler and yang, 2002).

The density of pore-water (in $\mathrm{kg} / \mathrm{m}^{3}$ ) follows (Waite et al., 2007 after Weast, 1987):

$\rho_{\mathrm{w}}=999.9+5.33010^{-2}(\mathrm{~T}-273)-6.83410^{-3}(\mathrm{~T}-273)^{2}$;

The density of sediment is taken as $\rho_{\mathrm{s}}=2700 \mathrm{~kg} / \mathrm{m}^{3}$, while the density of hydrate (in $\mathrm{kg} / \mathrm{m}^{3}$ ) follows (Waite et al., 2007 after Shpakov et al., 1998):

$\rho_{\mathrm{h}}=926.45-0.239(\mathrm{~T}-273)-3.7310^{-4}(\mathrm{~T}-273)^{2}$.

In the presence of hydrate, the pore-water relative permeability, assuming a pore-filing presence of hydrate, is given by (Kleinberg et al., 2003):

$\mathrm{k}_{\mathrm{rs}}=1-\mathrm{S}_{\mathrm{h}}^{2}+2\left(1-\mathrm{S}_{\mathrm{h}}\right)^{2} / \ln \left(\mathrm{S}_{\mathrm{h}}\right)$;

In the presence free gas, saturation dependant relative permeability and capillarity pressure are taken after Moridis and Sloan (2007):

$\mathrm{k}_{\mathrm{rw}}=\left(\left(\mathrm{S}_{\mathrm{w}}-\mathrm{S}_{\mathrm{rw}}\right) /\left(1-\mathrm{S}_{\mathrm{rw}}\right)\right)^{4}$ and $\mathrm{k}_{\mathrm{rg}}=\left(\left(\mathrm{S}_{\mathrm{g}}-\mathrm{S}_{\mathrm{rg}}\right) /\left(1-\mathrm{S}_{\mathrm{rw}}\right)\right)^{4}$,

when saturations exceed the irreducible saturations $\mathrm{S}_{\mathrm{rw}}=0.275, \mathrm{~S}_{\mathrm{rg}}=0.0125$;

$\mathrm{P}_{\text {cap }}\left(\mathrm{S}_{\mathrm{w}}\right)=-\mathrm{P}_{\mathrm{co}}\left[\left(\mathrm{S}^{*}\right)^{-1 / \mathrm{m}}-1\right]^{-\mathrm{m}}, \mathrm{S}^{*}=\left(\mathrm{S}_{\mathrm{w}}-\mathrm{S}_{\mathrm{ra}}\right) /\left(\mathrm{S}_{\mathrm{rs}}-\mathrm{S}_{\mathrm{ra}}\right)$,

With $\mathrm{m}=0.45, \mathrm{P}_{\mathrm{co}}=2000 \mathrm{~Pa}$, and the irreducible saturations $\mathrm{S}_{\mathrm{rs}}=0.895, \mathrm{~S}_{\mathrm{ra}}=0.19$;

For the gas phase:

$\mathrm{U}_{\mathrm{g}}=-\mathrm{K} \mathrm{k}_{\mathrm{rg}} / \mu_{\mathrm{g}}\left(\nabla \mathrm{P}_{\mathrm{g}}+\rho_{\mathrm{g}} \mathrm{g}\right)$, where the gas partial pressure is $\mathrm{P}_{\mathrm{g}}=\mathrm{P}_{\mathrm{w}}+\mathrm{P}_{\text {cap }}\left(\mathrm{S}_{\mathrm{w}}\right)$;

The molar volume of methane, and in turn its density, for a non-ideal gas is given by:

$\mathrm{P}_{\mathrm{g}} \mathrm{V}=\mathrm{Z} \mathrm{nRT}$,

where $\mathrm{Z}$ is the methane compressibility factor. Gasem et al. (2001) propose a modified PengRobinson equation of state with the temperature dependence that improves vapor pressure predictions for supercritical gases (in $\mathrm{Pa}$ ), and given by: 
$\mathrm{P}_{\mathrm{g}}=\mathrm{RT} /(\mathrm{v}-\mathrm{b})-\mathrm{a} /[\mathrm{v}(\mathrm{v}+\mathrm{b})+\mathrm{b}(\mathrm{v}-\mathrm{b})]$,

where $\mathrm{R}$ is the gas constant, $\mathrm{v}$ the molar volume, $\mathrm{T}_{\mathrm{c}}\left(=190.564^{\circ} \mathrm{K}\right)$ the critical temperature, $\mathrm{P}_{\mathrm{c}}$ $(=4.5992 \mathrm{MPa})$ the critical pressure, and $\omega(=0.011406)$ the acentric factor of methane; $\mathrm{a}$ and $\mathrm{b}$ are EOS constants, given by:

$\mathrm{a}=0.45724 \mathrm{R}^{2} \mathrm{~T}^{2} / \mathrm{P}_{\mathrm{c}} \exp \left\{\left(\mathrm{A}+\mathrm{BT} / \mathrm{T}_{\mathrm{c}}\right)\left[1-\left(\mathrm{T} / \mathrm{T}_{\mathrm{c}}\right)^{\alpha}\right]\right\}$,

$\mathrm{b}=0.0778 \mathrm{RT}_{\mathrm{c}} / \mathrm{P}_{\mathrm{c}}$,

$\alpha=\mathrm{C}+\mathrm{D} \omega+\mathrm{E} \omega^{2}$,

$\mathrm{A}=2.00 \mathrm{~B}=0.836 \mathrm{C}=0.134 \mathrm{D}=0.508 \mathrm{E}=-0.0467$.

Again, instead of solving the thermodynamic equilibrium at every node for every time step of our calculations, we interpolate the methane compressibility factor Z from a table of 201 precomputed values 273 to $393^{\circ} \mathrm{K}$ and 1 to $100 \mathrm{MPa}$.

Then, the gas viscosity $\mu_{\mathrm{w}}$ (in $\mathrm{Pa}^{*} \mathrm{~s}$ ) is given by Selim and Sloan (1989):

$\mu_{\mathrm{g}}=2.450410^{-3}+2.876410^{-5} \mathrm{~T}+3.27910^{-9} \mathrm{~T}^{2}-3.783810^{-12} \mathrm{~T}^{3}+2.089110^{-5} \rho_{\mathrm{g}}+2.512710^{-7}$

$\rho_{\mathrm{g}}{ }^{2}-5.82210^{-10} \rho_{\mathrm{g}}{ }^{3}+1.837810^{-13} \rho_{\mathrm{g}}{ }^{4}$

\subsection{Energy Balance}

$\partial\left[(1-\Phi) \rho_{\mathrm{s}} \mathrm{H}_{\mathrm{s}}+\Phi\left(\mathrm{M}_{\mathrm{w}} \mathrm{H}_{\mathrm{w}}+\mathrm{M}_{\mathrm{g}} \mathrm{H}_{\mathrm{g}}+\mathrm{M}_{\mathrm{h}} \mathrm{H}_{\mathrm{h}}\right)\right] / \partial \mathrm{t}+\nabla\left(\mathrm{U}_{\mathrm{w}} \mathrm{H}_{\mathrm{w}}\right)+\nabla\left(\mathrm{U}_{\mathrm{g}} \mathrm{H}_{\mathrm{g}}\right)=\nabla(\lambda \nabla \mathrm{T})+\mathrm{F}_{\mathrm{H}}$,

where $H_{s}$ is the enthalpy for the sediment matrix, $\lambda$ is the thermal conductivity of the compound, and $\mathrm{F}_{\mathrm{H}}$ is the heat generation term which account for internal sources (radiogenic heat, for instance). Enthalpy changes related to dissolved methane are considered negligible. We can then develops the energy balance into a thermal balance (e.g. Sun et al., 2005; He et al, 2006; Esmaeilzadeh et al., 2008), noting that:

$\mathrm{dH}_{\mathrm{i}}=\partial \mathrm{H}_{\mathrm{i}} / \partial \mathrm{T} \mathrm{dT}+\partial \mathrm{H}_{\mathrm{i}} / \partial \mathrm{P}_{\mathrm{i}} \mathrm{dP}_{\mathrm{i}}=\mathrm{Cp}_{\mathrm{i}} \mathrm{dT}+\sigma_{\mathrm{i}} \mathrm{dP}_{\mathrm{i}}$, for $\mathrm{i}=\mathrm{w}, \mathrm{g}, \mathrm{h}$,

where $\mathrm{Cp}_{\mathrm{i}}$ are the heat capacity and $\sigma_{\mathrm{i}}$ the throttling coefficient for the $\mathrm{i}^{\text {th }}$ phase, respectively; Inserting then the mass balance equations, and defining the latent heat of hydrate dissociation $\Delta \mathrm{H}_{\mathrm{D}}$ with:

$\dot{\mathrm{g}}_{\mathrm{g}} \mathrm{H}_{\mathrm{g}}+\dot{\mathrm{g}}_{\mathrm{w}} \mathrm{H}_{\mathrm{w}}+\dot{\mathrm{g}}_{\mathrm{h}} \mathrm{H}_{\mathrm{h}}=-\dot{\mathrm{g}}_{\mathrm{h}} \Delta \mathrm{H}_{\mathrm{D}}$,

then, a single-temperature thermal equilibrium (neglecting any heat barriers between phases) obeys (Sun et al., 2005):

$\left[(1-\Phi) \rho_{\mathrm{s}} \mathrm{Cp}_{\mathrm{s}}+\Phi\left(\rho_{\mathrm{w}} \mathrm{S}_{\mathrm{w}} \mathrm{C} \mathrm{p}_{\mathrm{w}}+\rho_{\mathrm{g}} \mathrm{S}_{\mathrm{g}} \mathrm{Cp}_{\mathrm{g}}+\rho_{\mathrm{h}} \mathrm{S}_{\mathrm{h}} \mathrm{C} \mathrm{p}_{\mathrm{h}}\right)\right] \partial \mathrm{T} / \partial \mathrm{t}+\mathrm{Cp}_{\mathrm{w}} \nabla\left(\mathrm{U}_{\mathrm{w}} \mathrm{T}\right)+\mathrm{C} \mathrm{p}_{\mathrm{g}} \nabla\left(\mathrm{U}_{\mathrm{g}} \mathrm{T}\right)-\nabla(\lambda \nabla \mathrm{T})=$ $\Phi \sigma_{\mathrm{g}}\left(\partial \mathrm{P}_{\mathrm{g}} / \partial \mathrm{t}-\mathrm{U}_{\mathrm{g}} \nabla \mathrm{P}_{\mathrm{g}}\right)-\dot{\mathrm{g}}_{\mathrm{h}} \Delta \mathrm{H}_{\mathrm{D}}+\mathrm{F}_{\mathrm{H}}$, 
where the effect of pressure on enthalpy for water and hydrate are neglected $\left(\sigma_{\mathrm{w}}=\sigma_{\mathrm{h}}=0\right)$, the isothermal methane throttling is $\sigma_{\mathrm{g}}=-1.510^{-4} \mathrm{~J} / \mathrm{kg} /{ }^{\circ} \mathrm{K}$ (Sun et al., 2005), the isobaric specific heat data (in $\mathrm{J} / \mathrm{kg} /{ }^{\circ} \mathrm{K}$ ) and the latent heat of hydrate dissociation above quadruple point $\Delta \mathrm{H}_{\mathrm{D}}$ (in $\mathrm{kJ} / \mathrm{kg}$ ) are given by Selim and Sloan (1989):

$\mathrm{Cp}_{\mathrm{w}}=4023.976+0.57736 \mathrm{~T}-8.31410^{-5} \mathrm{~T}^{2}$,

$\mathrm{Cp}_{\mathrm{g}}=1238.79+3.1303 \mathrm{~T}+7.90510^{-5} \mathrm{~T}^{2}-6.85810^{-7} \mathrm{~T}^{3}$,

$\mathrm{Cp}_{\mathrm{h}}=2200, \mathrm{Cp} \mathrm{p}_{\mathrm{s}}=835$ are constant,

$\Delta \mathrm{H}_{\mathrm{D}}=446.12-0.132638 \mathrm{~T}$, between 273 and $298^{\circ} \mathrm{K}$;

However, recent data indicates that $\Delta \mathrm{H}_{\mathrm{D}}$ is insensitive to pressure and temperature for conditions typical in terrestrial applications, remaining in the range $454.43 \pm 11.94 \mathrm{~kJ} / \mathrm{kg}$ between 5.5 and 19.3 $\mathrm{MPa}$ and 280.5 and $291.5^{\circ} \mathrm{K}$ (Gupta et al., 2008).

The thermal conductivity of methane is interpolated from a table of 201 pre-computed values from the WebBook of Chimistry at NIST (http://webbook.nist.gov) between 273 to $393{ }^{\circ} \mathrm{K}$ and 1 to $100 \mathrm{MPa}$. The thermal conductivities for water, and hydrate (in $\mathrm{W} / \mathrm{m} /{ }^{\circ} \mathrm{K}$ ) are given by Waite et al., 2007:

$\lambda_{\mathrm{w}}=0.562+1.7510^{-3}$ (T-273), (after Weast, 1987);

$\lambda_{\mathrm{h}}=0.624-2.7810^{-3}$ (T-273), (measured at $31.5 \mathrm{MPa}$, between 253 and $290{ }^{\circ} \mathrm{K}$ );

The thermal conductivity of the pore-fluid (water and gas) is taken as :

$\lambda_{\mathrm{wg}}=\mathrm{S}_{\mathrm{w}} \lambda_{\mathrm{w}}+\mathrm{S}_{\mathrm{g}} \lambda_{\mathrm{g}}$

Then, the thermal conductivity $\lambda$ of sediment, hydrate and pore-fluid compound is given by a nested Revil-type mixing rule according to Waite et al. (2007) of the form:

$\lambda_{\mathrm{f}}=\lambda_{\mathrm{h}}+\left(\lambda_{\mathrm{wg}}-\lambda_{\mathrm{h}}\right)\left(1-\mathrm{S}_{\mathrm{h}}\right)^{2} / 2\left\{1-\lambda_{\mathrm{h}} / \lambda_{\mathrm{wg}}+\left[\left(1-\lambda_{\mathrm{h}} / \lambda_{\mathrm{wg}}\right)^{2}+4 \lambda_{\mathrm{h}} / \lambda_{\mathrm{wg}} /\left(1-\mathrm{S}_{\mathrm{h}}\right)^{2}\right]^{0.5}\right\}$

$\lambda=\lambda_{\mathrm{s}}+\left(\lambda_{\mathrm{f}}-\lambda_{\mathrm{s}}\right) \Phi^{2} / 2\left\{1-\lambda_{\mathrm{s}} / \lambda_{\mathrm{f}}+\left[\left(1-\lambda_{\mathrm{s}} / \lambda_{\mathrm{f}}\right)^{2}+4 \lambda_{\mathrm{s}} / \lambda_{\mathrm{f}} / \Phi^{2}\right]^{0.5}\right\}$

\subsection{Numerical Resolution}

Our set of differential equations is solved with a mixed finite element in space and finitedifference in time scheme, programmed for the time being in 2-dimentions, with FreeFem++ (developed at the Laboratoire Jacques-Louis Lions in Paris). FreeFem++ benefits from high level programming language and advanced numerical solvers. Also, FreeFem++ allows presently parallelized 3-dimensional variational formulations. In this paper, the governing equations of time-dependant Temperature $T$, brine Pressure $P_{w}$, masses $M_{i}$ (or pore volume saturations $\mathrm{S}_{\mathrm{i}}$ ), and fluid fluxes $\mathrm{U}_{\mathrm{i}}$ unknowns, for $\mathrm{i}=\mathrm{w}, \mathrm{g}, \mathrm{h}$, are solved with a backward Euler method at each time step in a sequential manner: the momentum equations (11) and (18) are 
solved first, followed by the single-temperature thermal equilibrium (29), then mass balances (5), (6) and (4). Although the methane mass balance (6) contains 3 unknowns $M_{d}, M_{g}$, and $\mathrm{M}_{\mathrm{h}}$, this apparently under-determined system can be solved, however, by realizing that all three cannot be the primary dependent variable at any given time (Bathnagar et al. 2007): As long as the methane concentration in pore fluid is lower than the local solubility, $\mathrm{M}_{\mathrm{d}}$ is the primary variable and $\mathrm{M}_{\mathrm{g}}=\mathrm{M}_{\mathrm{h}}=0$. Once dissolved methane exceeds solubility, $\mathrm{M}_{\mathrm{d}}$ is set equal to the solubility, and excess methane goes into the hydrate phase within the GHSZ (equations 4 and 5), and into free gas bellow the BGHSZ. The relevant parameters to each governing equations are updated prior to solving.

Also, concentration of salt ions $(\mathrm{Na}$ and $\mathrm{Cl})$ also impact on the dissociation pressures $\mathrm{P}_{\mathrm{w}}{ }^{\text {dis }}$ and methane solubility (equation 1-4). Therefore, we incorporated an additional mass balance for chlorine (or sodium) in the pore fluid, where $M_{c}$ is the Mass of salt ion, and $D_{c}=1.0110^{-9} \mathrm{~m}^{2} / \mathrm{s}$ its diffusion coefficient:

$\left[\partial \Phi \sum \mathrm{M}_{\mathrm{c}} / \partial \mathrm{t}+\sum \mathrm{U}_{\mathrm{w}} \mathrm{M}_{\mathrm{c}}\right]=\nabla\left(\Phi \mathrm{D}_{\mathrm{c}} \nabla \mathrm{M}_{\mathrm{c}}\right)$,

We neglect, however, the evolution of salt concentration (and salt precipitation) in the momentum and energy balances.

The boundary conditions are the following: temperature is fixed and pressure is hydrostatic at the sea-floor; Constant heat flux and pore-water and gas vertical Darcy fluxes (zero horizontal fluxes) are imposed at the base of the model. The time-steps chosen in our simulations is constant and lower than the characteristic times for advection is $\tau_{\text {conv }}=\Phi \mathrm{h} / \mathrm{v} \mid$, and diffusion $\tau_{\mathrm{conv}}=\lambda \mathrm{h}^{2} / \mathrm{v} \mid$, where $\mathrm{h}$ is the representative elemental length given by half the distance between the centroid of an element and its boundary (Zabras and Samanta, 2002). Our simulations are performed on 13810 elements with 7110 vectrices, with average elemental half-length $\mathrm{h}=18.5$ $\mathrm{m}$, characteristic times $\tau_{\mathrm{conv}}=10^{10} \mathrm{~s}$, and lasting about 300 minutes on a personal computer. Furthermore, solving the momentum equations (11) and (18) requires a mixed variational formulation, approximating simultaneously both pressure and velocity field (e.g. Masud, 2002): A standard Galerkin approach shows the lack of stability, with a wildly oscillating pressure field if arbitrary combinations of interpolation functions are employed, and the corresponding mass balance equation is satisfied in an extremely weak sense. In our study, Darcy fluxes are approximated with the P2dc discontinuous FE, and the pressure, as well as all other unknowns and parameters, with the P1 continuous FE. 
An other approach, proposed by He et al. (2006), consists in solving explicitly the pressure

$\left.\Phi\left(\varepsilon_{\mathrm{w}} \mathrm{S}_{\mathrm{w}} / \rho_{\mathrm{w}}+\varepsilon_{\mathrm{g}} \mathrm{S}_{\mathrm{g}} / \rho_{\mathrm{g}}\right)\right] \partial \mathrm{P}_{\mathrm{w}} / \partial \mathrm{t}-\left(\mathrm{Kk}_{\mathrm{rw}} \mathrm{k}_{\mathrm{rs}} / \mu_{\mathrm{w}}+\mathrm{Kk}_{\mathrm{rg}} / \mu_{\mathrm{g}}\right) \nabla \mathrm{P}_{\mathrm{w}}-\left(\mathrm{Kk}_{\mathrm{rw}} \mathrm{k}_{\mathrm{rs}} / \mu_{\mathrm{w}} / \rho_{\mathrm{w}} \nabla \rho_{\mathrm{w}}+\mathrm{Kk}_{\mathrm{rg}} / \mu_{\mathrm{g}} / \rho_{\mathrm{g}} \nabla \rho_{\mathrm{g}}\right)=$ $\mathrm{g} / \rho_{\mathrm{w}} \nabla\left(\mathrm{K} \rho_{\mathrm{w}}{ }^{2} \mathrm{k}_{\mathrm{rw}} \mathrm{k}_{\mathrm{rs}} / \mu_{\mathrm{w}}\right)+\mathrm{g} / \rho_{\mathrm{g}} \nabla\left(\mathrm{K} \rho_{\mathrm{g}}{ }^{2} \mathrm{k}_{\mathrm{rg}} / \mu_{\mathrm{g}}\right)+\dot{\mathrm{g}}_{\mathrm{w}} / \rho_{\mathrm{w}}+\dot{\mathrm{g}}_{\mathrm{g}} / \rho_{\mathrm{g}}$,

with the isothermal compressibility of water $\varepsilon_{\mathrm{W}}=4.2510^{-10} \mathrm{~Pa}^{-1}$ and gas $\varepsilon_{\mathrm{g}}=8.510^{-9} \mathrm{~Pa}^{-1}$.

In the simulations presented in the following sections, where hydrate formation is a slow process, both mixed variational and explicit pressure formulations lead to stable, nearly identical solutions: brine pressure remains sub-hydrostatic. We also performed each simulation with 5-times smaller and 5-times larger time-steps, and found no significant differences in the solutions.

When higher accuracy for the pressure, and mass fluxes is required, a well known approach to the Darcy flow is the dual mixed formulation developed by Raviart and Thomas (1977) using divergence based finite element spaces for the velocity field combined with discontinuous Lagrangian spaces for the potential. Finite-element modeling of phase transitions in multiphase fluid flowing though porous media has since received considerable attention (e.g. Bernadi et al., 2002; Hughes et al., 2006; Nakshatrala et al., 2006), leading to variational multiscale approaches, for instance with a volumetric, residual-based, stabilization term that does not involve any mesh-dependent parameters (Hughes et al., 2006). Further more, the standard Galerkin finite element method again results in non-convergence for advectiondominated diffusion and transient convective-diffusive heat transfer phenomena (Ayub and Masud, 2003): thus for the thermal equilibrium, a mixed formulation of scalar temperature and temperature flux may be implemented in the Galerkin finite element formulation with a least-squares form of the residuals that are based on the corresponding Euler-Lagrange equations. In the near future, we will investigate the potential of such residual formulations on our simulator.

A collaborative effort to compare the world's leading gas hydrate reservoir simulators has been initiated, and in 2008 five different reservoir simulators (CMG STARS, HydrateResSim, MH-21 HYDRES, STOMP-HYD, and TOUGH+HYDRATE) participated in the simulation of five problems of increasing complexity (Wilder et al., 2008). In it's current form, our simulator is probably not ready to undergo such benchmarks, as its design is focused on largescale and slow geological processes. Moreover, no comparison between simulations of natural gas hydrate emplacement has been proposed so far, and our simulations can't be benchmarked 
against previously published scenarios. As a matter of facts, the coupling between thermodynamics, kinetics, and transport processes from the microscopic to the geologic scale presents additional numerical challenges: in particular external forces acting on the model, such as sedimentation, tectonic forces, eustatic sea-level and bottom water temperature changes; More importantly, internal processes such as compaction and the resulting porewater flow, coupled to both the structure's deformation and the initiation of fractures via the evolution of the mechanical strength and the effective stress in the structure, are unaccounted in our model. We do not therefore propose to simulate a realistic history of hydrate emplacement though a particular geological episode. However, our current framework appears sufficient to examine, in an ideally stable geological system, the formation and distribution of methane hydrate and free gas, with respect to the geothermal gradient, fluids advection rates, the methane in-situ and basal sources. In particular, the aim of this study is to estimate the efficiency of hydrate emplacement with respect to sources of methane (it's budget), and to outline if, and how, along strike variation in hydrate emplacements arise in the 2-dimentional model.

\section{Case Study}

\subsection{Initial Conditions}

Our case study consists of an anticlinal structure, $6250 \mathrm{~m}$ in width, resting on a $7^{\circ}$ landward dipping base. It consists from left to right of a $1 \mathrm{~km}$ wide plateau lying in $2000 \mathrm{~m}$ water depth, followed by a $1.5 \mathrm{~km}$ wide $-350 \mathrm{~m}$ deep syncline (slope basin), a $1.5 \mathrm{~km}$ wide $-350 \mathrm{~m}$ high anticline, a $0.67 \mathrm{~km}$ wide critical slope at $40^{\circ}$ angle, and a $670 \mathrm{~m}$ flat at $2575 \mathrm{~m}$ depth to the right.

The porosity is $64 \%$ at the sea-floor, and follows an exponential decay with sub-bottom depth $\mathrm{z}$ given as:

$\Phi(\mathrm{z})=\Phi_{\infty}-\left(\Phi_{0}-\Phi_{\infty}\right) * \exp (\beta \mathrm{z})$, with $\Phi_{0}=0.64, \Phi_{\infty}=0.3$, and $\beta=2.10^{-4}$.

No methane is present initially, and the brine pressure is hydrostatic. Salt ions content in the 2-phase domain is $3.9 \mathrm{wt} \%$ and $\mathrm{Cl}=19 \mathrm{ppt}$ in the 3-phase domain. Solely chlorine content is tracked henceforth.

The bottom water temperature is fixed at $275^{\circ} \mathrm{K}$ and a $55 \mathrm{~mW} / \mathrm{m}^{2}$ basal heat flux is imposed for the temperature initial solution (Fig. 2): in the deeper part of the model a homogeneous geothermal gradient of $0.4^{\circ} / \mathrm{km}$ is established, but the gradient reaches $0.7^{\circ} / \mathrm{km}$ at the axis of the slope basin and decreases to $0.3 \% / \mathrm{km}$ at the crest of the anticline. This wide range in 
geothermal gradient, due to the large variations of the sea-floor depth across the model, in an otherwise homogeneous pressure gradient has two important consequences:

a) The free methane density acquires structurally related values (Fig. 3), with relatively homogeneous values in excess of $230 \mathrm{~kg} / \mathrm{m}^{3}$ at depth grater than $2600 \mathrm{~m}$, but decreasing rapidly with pressure above, reaching $150 \mathrm{~kg} / \mathrm{m}^{3}$ at the crest of the anticline.

b) The methane solubility also acquires structurally related variations (Fig. 4): at sea-floor $\left(275^{\circ} \mathrm{K}\right), 1 \mathrm{~kg}$ of seawater holds up to $0.6 \mathrm{~g}$ of methane; at the BGHSZ the solubility reached its maximum of $1.5 \mathrm{~kg} / \mathrm{m}^{3}$ : thus from the BGHSZ, methane precipitation from the dissolved phase is increasingly possible toward the sea-floor, but the dissolution gradient is nearly 5 times larger at the foot of the anticline and in the slope basin $(4 \mathrm{~g} / \mathrm{m})$ than in the anticline $(0.75 \mathrm{~g} / \mathrm{m})$. Below the BGHSZ, the solubility drops with increasing pressure (and temperature to a lesser degree), providing opportunity for the presence of free methane, decreasing more rapidly in the slope basin $(-1 \mathrm{~g} / \mathrm{m})$ than in the anticline $(-0.5 \mathrm{~g} / \mathrm{m})$. However, free gas is more likely observed at the crest of the anticline, where the solubility below the BGHZ is at its minimum.

Therefore in conditions of forming hydrate, i.e. methane in excess of the solubility, the vertical gradient of the solubility induces through diffusion consistent upward transport of dissolved methane in the stability zone and downward transport below. In order to continuously exsolve methane and to precipitate hydrate, this diffusive flux need to be refurbished, as pointed out by $\mathrm{Xu}$ and Ruppel (1999) or Davie et al. (2004), by in-situ biogenic generation, advection of free/dissolved methane from below, porosity loss, or a combination of these mechanisms.

This intrinsic methane flux, or its equivalent brine flux, if the system is fed solely from its base by dissolved methane and assuming full dissolution, can be approximated by:

$\partial \Phi \mathrm{M}_{\mathrm{d}} / \partial \mathrm{t}=0$ and $\mathrm{U}_{\mathrm{g}}=-\Phi \mathrm{D}_{\mathrm{d}}^{\mathrm{g}} \nabla_{\mathrm{z}} \mathrm{M}_{\mathrm{d}}^{\mathrm{g}}$, or $\mathrm{U}_{\mathrm{w}}=-\Phi \mathrm{D}_{\mathrm{d}}^{\mathrm{g}} \nabla_{\mathrm{z}} \mathrm{M}_{\mathrm{d}}^{\mathrm{g}} / \mathrm{M}_{\mathrm{d}}^{\mathrm{g}}$,

In our model, the local solubility gradient imposes an upward intrinsic methane transport of $2.510^{-13} \mathrm{~kg} / \mathrm{m}^{2} / \mathrm{s}$ at the crest of the anticline to $1.410^{-12} \mathrm{~kg} / \mathrm{m}^{2} / \mathrm{s}$ in the slope basin (or 0.5 to $2.5 \mathrm{~mol} / \mathrm{m}^{2} / \mathrm{kyr}$ ), or its equivalent pore-water flux of $210^{-13}$ to $1.310^{-12} \mathrm{~kg} / \mathrm{m}^{2} / \mathrm{s}$ (Fig. 5). Below the BGHSZ, the downward intrinsic methane transport reaches $-210^{-13} \mathrm{~kg} / \mathrm{m}^{2} / \mathrm{s}$ over several 10 of meters in the slope basin. 
Methane fluxes have been estimated at various active cold vent seep sites from deep sea drilling and sedimentary cores (Tab. 1). Strong methane activity often results in fluxes in excess of $10^{-12} \mathrm{~kg} / \mathrm{m}^{2} / \mathrm{s}$. At the Bush Hill mount, in the Gulf of Mexico, up to $3.810^{-7} \mathrm{~kg} / \mathrm{m}^{2} / \mathrm{s}$ are predicted in an area $250 \times 100 \mathrm{~m}$ wide (Chen and Cathles; 2005). Gas bubbles rising in tubes (Haeckel et al, 2007) similar to those observed in the Sea of Okhotsk, and leading to ebolution in the column, are attained with $2.810^{-12} \mathrm{~kg} / \mathrm{m}^{2} / \mathrm{s}$. Such fluxes are however generally localized: we fix methane production in our models at a more conservative $2.2510^{-}$

${ }^{13} \mathrm{~kg} / \mathrm{m}^{2} / \mathrm{s}$, close to the upward intrinsic methane transport. Brine fluxes are know to vary widely, reaching up to the fluid fluxes required for sediment fluidisation in mud volcanoes: $0.05 \mathrm{~cm} / \mathrm{s}$ for clay and silt, and $1 \mathrm{~cm} / \mathrm{s}$ for sands (Brown, 1990). For instance, Hakon Mosby Mud Volcano, the upflow velocities were estimated at 3-6 m/yr in the central area $\left(1-210^{-4}\right.$ $\mathrm{kg} / \mathrm{m}^{2} / \mathrm{s}$ ) and $0.3-1 \mathrm{~m} / \mathrm{yr}$ in Beggiatoa mats (de Beer et al., 2006). Other observed flows include $0.04 \mathrm{~m} / \mathrm{yr}$ in the Kazan Mud Volcano (Haese et al., 2003), and $0.1 \mathrm{~m} / \mathrm{yr}$ in sediments on Hydrate Ridge (Luff and Wallmann, 2003). In this study, we consider two case scenarios: case A - a conservative $2.2510^{-13} \mathrm{~kg} / \mathrm{m}^{2} / \mathrm{s}$, equal to the methane production rate, and case B a fluid seepage case with $5.62510^{-11} \mathrm{~kg} / \mathrm{m}^{2} / \mathrm{s}$, or 250 times that of case A.

\subsection{Simulations}

Simulations are performed over $1 \mathrm{Ma}$, at $2.5 \mathrm{kyr}$ time steps. Fig. 6 presents the methane budget, in either hydrate, free, or dissolved phase, throughout cases A and B simulations. Full dissolution is reached after 132.5 and $127.5 \mathrm{kyr}$ (in cases A and B respectively), with 6960 tons of methane stored in the pore fluids. Hydrate start to form after $55 \mathrm{kyr}$, and grow at constant rates of 19.8 and $25.5 \mathrm{ton} / \mathrm{yr}$. Soon after 90 and $85 \mathrm{kyr}$ and initially at the base of the model where full dissolution occurs first, free methane builds up in the structure at a rates of 46.6 and 45.4 ton/yr. While in case A less than 50 ton of methane seeps into the watercolumn, in case B 12 kton of pore-fluid pass across the sea-floor carrying 6,996 tons of dissolved methane (i.e. $9.7 \%$ ) out of the model.

The total area of the structure is $9.47 \mathrm{~km}^{2}\left(5.6 \mathrm{~km}^{2}\right.$ of pore-space); The hydrate stability zone occupies $2.32 \mathrm{~km}^{2}$. Thus for case A, $67.4 \mathrm{kton}$ of methane are fed to the model during the simulation, corresponding to the sum of stored hydrate, free and dissolved methane. Case B totals 72.3 kton of methane, owning probably to the fixed basal boundary condition for $\mathrm{Ug}$, that forces extra methane to refurbish the dissolved methane carried upward with the higher brine flux. In the hydrate stability zone, 16.5 kton are generated in-situ: thus 2,261 tons of methane (i.e. $12 \%$ of formed hydrate) originate from beneath the GHSZ for case A, and 
7,656 tons of methane (i.e. $46 \%$ of formed hydrate - not counting the 6,996 tons of dissolved methane escaping at the top) for case B.

Fig. 7 and 8 show the free methane and hydrate saturations reached after 1 Ma for cases $\mathrm{A}$ and B. Figs. 9 shows vertical profiles of the free methane and hydrate saturation at the axis of the anticline and slope basin, with 25 kyr time steps; Figs. 10 shows vertical profiles of their respective fluxes at the same locations. Free methane saturation reach $0.6 \%$ after $1 \mathrm{Ma}$. As the free gas saturation increases with time, the relative permeability to gas flow grows from $10^{-22}$ to $10^{-20} \mathrm{~m}^{2}$, and vertical gas fluxes increase (Fig. 10). Then, lateral gas migration away from the axis of the syncline, due to the lower methane buoyancy and higher porosity (thus higher diffusivity), results in lower saturations and gentler free gas profiles in the syncline (Fig. 7): vertical methane fluxes only reach $1.510^{-12} \mathrm{~kg} / \mathrm{m}^{2} / \mathrm{s}$ at the bottom of the profile, against 2.5 $10^{-12} \mathrm{~kg} / \mathrm{m}^{2} / \mathrm{s}$ in the anticline. With a Peclet number close to 1 , diffusion greatly evens free gas concentrations across the model. Hydrate saturation after 1 Ma reaches very locally $50 \%$ and $70 \%$, for cases $\mathrm{A}$ and $\mathrm{B}$ respectively. The hydrate distribution is surprisingly even alongstrike in models, and rather similar between both cases (Fig. 8). Peak in hydrate saturation occurs in a $80 \mathrm{~m}$ thick zone located at the BGHSZ (Fig. 9). These peaks are laterally disconnected, separated into 10 to $250 \mathrm{~m}$ wide transects and characterized by higher dips than the BGHZ with their maxima always located down-dip (Fig. 7). This segmentation appears early on and remains stable during simulations. On one hand, the segments probably arise from the numerical in-accuracy of the mesh to represent the phase-discontinuity at the BGHSZ. On the other hand, their dip and position of maximum might arise from the permeability reduction during hydrate growth. The saturation drops to its minima $80 \mathrm{~m}$ above the BGHSZ, followed by a secondary saturation peak. The saturation then grows evenly across the rest of the GHSZ until approaching the sea-floor, at constant rates everywhere in case A and with slightly higher rate at the foot of the anticline and in the slope basin compared to the plateau and the anticline for case B. This discrepancy in hydrate saturation in the GHSZ can best be explain by the intrinsic dissolved methane flux, of $310^{-13} \mathrm{~kg} / \mathrm{m}^{2} / \mathrm{s}$ in the anticline and greater than $10^{-12} \mathrm{~kg} / \mathrm{m}^{2} / \mathrm{s}$ in the slope basin, which results from the solubility variations across our model. Thus, if full dissolution is reached at the BGHSZ, a slightly larger dissolved methane flux enters the slope basin than the anticline (Fig. 4), but the exolution of methane for hydrate precipitation is controlled by the solubility gradient. For case B, the pore-fluid flux is much larger than the intrinsic dissolved flux, and exolution proceeds at higher rates (over a thinner GHSZ) in the slope basin than in the anticline, 
emplacing therefore higher saturations. For case A, the intrinsic dissolved flux is not reached

In order to conclude our study, a third simulation is presented: Case A is transposed from $2000 \mathrm{~m}$ to $1000 \mathrm{~m}$ water depth. In order to keep the GHSZ to a self-similar thickness, we lower the basal heat flux from 55 to $45 \mathrm{~mW} / \mathrm{m}^{2}$. Thus for case $\mathrm{C}$, all other parameter are equal to those of case A. The GHSZ at the centre of slope basin for cases A and C is located at about the same sub-bottom depth, and the vertical profiles of the hydrate saturation are identical (Figs. 11), although free gas saturation is $50 \%$ higher. At the axis of the anticline, free methane forms an advective front that reaches $12 \%$ saturation just below the GHSZ during the last $100 \mathrm{kyr}$ of simulation. The overlying peak saturation is $50 \%$ (Figs. 11): case $\mathrm{C}$ is characterized by hydrate saturation rather similar to case A everywhere in the model, except for the anticline where the crest is underlain by a 500 wide and $75 \mathrm{~m}$ thick hydrate peak with saturations in excess of $40 \%$, bordered on either slopes by $40 \%$ saturation and almost $500 \mathrm{~m}$ wide transects. Above the peak, saturation profiles are identical in both cases $\mathrm{A}$ and $\mathrm{C}$. When examining the methane budget for case C (Fig. 6), it appears that case C's free methane mass, hydrate mass, and dissolver mass are slightly larger than cases $\mathrm{A}$ and $\mathrm{B}$. The prime discrepancy between these cases is the large decrease of free methane density (Fig. 3) when set in shallower water depths and approaching methane critical pressure: the methane compressibility dependence on temperature becomes negligible and the density grows linearly with hydrostatic pressure; Thus, the methane saturations between case $\mathrm{A}$ and $\mathrm{C}$ grow to gas density accordingly, without significant changes in total mass. Moreover, the higher free gas buoyancy, particularly in the anticline is responsible for the strong free gas flux that nourishes the hydrate peak at the base of the GHSZ. Secondly, the overall solubility decreases slightly, retaining case A's general shape (Fig. 4), with the exception of the anticline axis where the solubility is only $1.01 \mathrm{~kg} / \mathrm{m}^{3}$ at all depth below the BGHZ: dissolved methane transport into the GHSZ at the anticline decreases from case A to C. Finally, the intrinsic dissolved methane flux in both water depths remain very similar, owing to the self-similarity imposed on both models (i.e. similar thermal structure and GHSZ thickness), and hydrate emplacement above the hydrate peak in both models are very similar.

\section{Discussion and Conclusive Remarks}


The model proposed in this study is still in its infancy. However, our finite-element approach appears well suited for the simple numerical challenges performed in this study. At the rates of methane and water production imposed in our simulations, the proportion of hydrate growth versus total methane content is $27.7,33.4$, and $25.8 \%$ for cases $\mathrm{A}, \mathrm{B}, \mathrm{C}$, respectively: the systems investigated are rather inefficient with respect to hydrate emplacements, and act primarily as free gas accumulators; However, seepage of methane (through the top of the model) is negligible, as long as pore-fluid flow remains below $210^{-11} \mathrm{~kg} / \mathrm{m}^{2} / \mathrm{s}$. Moreover, for irreducible permeability ranging from $10^{-13}$ to $10^{-20} \mathrm{~m}^{2}$, the Darcy fluid and free gas flow does not exhibit focused flow, and the build up of hydrate emplacements is largely linear through time (Fig. 6). Toward the end of case $\mathrm{C}$ simulation, the buoyancy driven gas flow introduces dramatic hydrate growth rates at the BGHSZ, illustrating non-linear behavior. Hence, alternatives finite-element classes such as Raviart-Thomas elements could be implemented for solving the Darcy flows. Finally during our simulations, the temperature, pressure, and salinity do not deviate significantly from their initial profiles: these appear at production rates several order of magnitude larger. The temperature presents the largest changes: the temperature gradient at the crest of the anticline increases by $3.3,3.67,4.4 \%$ and in the slope basin by $3.7,4.0,3.65 \%$, for cases $\mathrm{A}, \mathrm{B}, \mathrm{C}$ respectively, due to the decrease of thermal conductivity in the GHSZ and the increase in methane advection below. Rapid hydrate formation/dissociation, resulting in important volume changes, latent heat, and fresh water exchange may be investigated in the future.

At present time, our model does not include other geochemical constituents, primarily organic content and sulfate: Methanogenesis is imposed as constant or as arbitrary time and space functions; Near the sea-floor, sulfate diffusion from the bottom water and subsequent sulfate reduction, anaerobic methane oxidation, and isotopic carbon fractionation are not modeled. As a result, our simulations predict amounts of forming hydrate near the sea-floor and gas seeping into the water column that need to be revised for the methane oxidation. These processes have been left out because numerous 1-dimensional models already exist that would be perfectly accurate at every location in our 2-D model.

A more obvious limitation of our model is that we don't consider sedimentation/erosion and consolidation (time-dependent porosity evolution). In an elegant approach often implemented in 1-D models linking the porosity-loss to effective stress (e.g. Bhatnagar, 2008; Haacke, 2008; Garg et al., 2008), the seafloor sedimentation rate $\hat{\mathrm{S}}$ is constant in time and in equilibrium with the subsidence rate, compensating compaction in the way that the depth- 
porosity profile remains constant through time, and introducing a downward sediment flux $\mathrm{U}_{\mathrm{s}}$, and fluid flux resulting from sedimentation and compaction $\mathrm{U}_{\mathrm{w}}{ }^{\text {sed }}$ in the form of (Bhatnagar, 2008):

$\mathrm{U}_{\mathrm{s}}=\left(1-\Phi_{0}\right) \hat{\mathrm{S}}$, and $\mathrm{U}_{\mathrm{w}}^{\mathrm{sed}}=\left(1-\Phi_{0}\right) /\left(1-\Phi_{\infty}\right) \Phi_{\infty} \hat{\mathrm{S}}$.

The main consequence of the downward sedimentary flux $U_{s}$ is hydrate dissociation at the base of the GHSZ and the consequent formation of a free gas zone, while the fluid flux $\mathrm{U}_{\mathrm{w}}{ }^{\text {sed }}$ adds to the user defined pore-water flow (boundary condition): this does not alter noticeably the conclusions of this study. Furthermore, sediment will often bypass structural highs and deposit preferentially in bathymetric lows: a laterally variable seafloor sedimentation rate will break the equilibrium with the subsidence rate, and result in time variant depth-porosity. Therefore, the process of consolidation may be more accurately accounted for when related to the rate of excess pore pressure dissipation and the rate of sedimentation (Sultan et al. 2004), and, if methane hydrate provide significant strength to the solidus, related to hydrate growth (e.g. Kimoto et al., 2007).

In the simulations presented in this study, along strike variations are mainly the result of the depth-dependence of pressure and sub-bottom dependence of temperature in the thermodynamics of hydrate emplacement. Methane and water production rates are held homogeneous, and the rheology is driven by sub-bottom depth, in particular the porosity: to a large extend, the simulation results are therefore 1-dimensional. Recently, Bhatnagar (2008) pointed out that the 1-dimentional steady-state solution for marine hydrate emplacements, when expressed in its dimensionless form, is relatively insensitive to changes in water depth, sea-floor temperature, and geothermal gradient: our simulations are an illustration of this invariance. Still, subtle along strike variations in the formation of free gas zones and hydrate saturations profiles result from significant changes in methane density and solubility (the intrinsic dissolved methane flux). Assigning to our models vertical fluid and methane conduits, or lateral migration paths along sedimentary bedding guided permeability layers for example, would introduce areas of focused flow and more pronounced heterogeneities on gas hydrate and free gas distribution: our model will shortly become parallel and 3-dimentional. However to render the complexity in natural hydrate emplacement, transport models coupled with sediment mechanics, through fracture initiation and propagation, might prove more critical.

\section{Nomenclature}

$\mathrm{Cp}_{\mathrm{i}}$ Specific heat $\left[\mathrm{J} / \mathrm{kg} /{ }^{\circ} \mathrm{K}\right]$ 
$D_{i}^{j}$ Bulk diffusivity of specie in phase $\mathrm{j}\left[\mathrm{m}^{2} / \mathrm{s}\right]$

$\varepsilon_{\mathrm{i}}$ Compressibility $\left[\mathrm{Pa}^{-1}\right]$

$\mathrm{F}_{\mathrm{i}}$ Generation term $\left[\mathrm{kg} / \mathrm{m}^{2} / \mathrm{s}\right]$

g Gravitational acceleration $\left[9.81 \mathrm{~m} / \mathrm{s}^{2}\right]$

$\mathrm{H}_{\mathrm{i}}$ Enthalpy [J]

i Index of reactive specie $[\mathrm{w}, \mathrm{g}, \mathrm{h}, \mathrm{d}]$

$\mathrm{j}$ Index of phase $[\mathrm{a}, \mathrm{g}, \mathrm{s}]$

$\mathrm{k}_{\mathrm{i}}$ Relative Permeability [ $\left.\mathrm{m}^{2}\right]$

$\mathrm{L}_{\mathrm{h}}$ Latent heat of hydrate dissociation $[\mathrm{J} / \mathrm{kg}]$

$\mathrm{M}_{\mathrm{i}}$ Mass per unit Volume $\left[\mathrm{kg} / \mathrm{m}^{3}\right]$

$\mathrm{P}_{\mathrm{i}}$ Partial pressure $[\mathrm{Pa}]$

$\mathrm{P}_{\mathrm{c}}$ Methane critical pressure [4.5992 $\mathrm{MPa}$ ]

R Gas constant

$\mathrm{T}$ Temperature $\left[{ }^{\circ} \mathrm{K}\right]$

$\mathrm{T}_{\mathrm{c}}$ Methane critical temperature $\left[190.564^{\circ} \mathrm{K}\right]$

$\mathrm{U}_{\mathrm{i}}$ Darcy mass flux $\left[\mathrm{Kg} / \mathrm{m}^{2} / \mathrm{s}\right]$

$\mathrm{v}$ Molar volume $\left[\mathrm{m}^{3} / \mathrm{mol}\right]$

$\nabla$ Gradient $(\partial / \partial \mathrm{x}, \partial / \partial \mathrm{y})$

$\lambda_{\mathrm{i}}$ Thermal conductivity $\left[\mathrm{W} /{ }^{\circ} \mathrm{K} / \mathrm{m}\right]$

$\mu_{\mathrm{i}}$ Viscosity [Pa*s]

$\Phi$ Porosity

$\rho_{\mathrm{i}}$ Density $\left[\mathrm{kg} / \mathrm{m}^{3}\right]$

$\sigma_{\mathrm{i}}$ the throttling coefficient $\left[\mathrm{J} / \mathrm{kg} /{ }^{\circ} \mathrm{K}\right]$

$\omega$ Methane acentric factor

\section{References}

Ayub, M., and Masud, A., 2003. A new stabilized formulation for convective-diffusive heat transfer. Numerical Heat Transfer, Part B, 44, 1-23, doi:10.1080/10407790390121989

Bhatnagar, G., Chapman, W.G., Dickens, G.R., Dugan, B., Hirasaki, G.J., 2007. Generalization of gas hydrate distribution and saturation in marine sediments by scaling of thermodynamic and transport processes, American Journal of Science, 307, 861-900 Bhatnagar, G., 2008. Accumulation of gas hydrates in marine sediments. Doctor of Philosophy, Rice University, pp. 1-294 
Bernadi, C., Pironneau, O., 2002. Derivative with respect to discontinuities in the porosity. Comptes Rendus de l'Académie des Sciences, Paris, 335, 661-666.

Brown, K.M., 1990. The nature of hydrogeologic significance of mud diapirs and diatremes for accretionary systems. Journal of Geophysical Research, 95, B6, 8969-8982.

Chapoy, A., Mohammadi, A.H., Richon, D., Tohidi, B., 2004. Gas solubility measurements and modeling for methane-water and methane-n-butane-water systems at low temperature conditions. Fluid Phase Equilibria, 220, 113-121.

Chen, D., Cathles, L.M., 2005. On the thermal impact of gas venting and hydrate crystallization. Journal of Geophysical Research, 110, B11204, doi:10.1029/2004JB003533.

Clennell, M.B., Hovland, M., Booth, J. S., Henry, P., Winters, W. J., 1999. Formation of natural gas hydrates in marine sediments 1 . Conceptual model of gas hydrate growth conditioned by host sediment properties. Journal of Geophysical Research, 104, 22985 23003.

Davie, M.K. Buffett, B.A., 2003. Sources of methane for marine gas hydrate: inferences from a comparison of observations and numerical models. Earth and Planetary Science Letters, 206, 51-63.

Davie, M.K., Zatsepina, O.Y., Buffett, B.A., 2004. Methane solubility in marine hydrate environments. Marine Geology, 203, 177-184.

De Beer, D., Sauter, E., Niemann, H., Kaul, N., Foucher, J.P., Witte, U., Schluter, M., Boetius, A., 2006. In situ fluxes and zonation of microbial activity in surface sediments of the Hakon Mosby Mud Volcano. Limnol. Oceanographie, 51, 1315-1331.

Duan, Z., Moller, N., Weare, J. H., 1992. An equation of state for the CH4-CO2-H2O system: 1. Pure systems from 0 to $1000 \_c$ and 0-8000 bar. Geochimica et Cosmochimica Acta, $56,2605-2617$.

Duan, Z., Mao, S.-A., 2006. Thermodynamic model for calculating methane solubility, density and gas phase composition of methane-bearing aqueous fluids from 273 to 523 $\mathrm{K}$ and from 1 to 2000 bar. Geochimica et Cosmochimica Acta, 3369:3386.

Esmaeilzadeh, F., Zeighami, M.E., Fathi, J., 2008. 1-D Modeling of Hydrate Decomposition in Porous Media. International Journal of Chemical and Biological Engineering 1:4, $208-214$

Fowler, A.C., Yang, X.-S., 2002. Loading and unloading of sedimentary basins: The effect of rheological hysteresis. Journal of Geophysical Research, Vol. 107, B4, 2058, doi:10.1029/2001JB000389 
Gasem, K.A.M., Gao, W. Pan, Z., Robinson Jr., R.L., 2001. A modified temperature dependence for the Peng-Robinson equation of state. Fluid Phase Equilibria, 181, 113125

Garg, S.K. Pritchett, , J.W. , Katoh, A., Baba, K., Fujii, T., 2008. A mathematical model for the formation and dissociation of methane hydrates in the marine environment. Journal of Geophysical Research, Vol. 113, B01201, doi:10.1029/2006JB004768.

Genov, G., Kuhs, W.F., Staykova, D.K., Goreshnik, E., Salamatin, A.N., 2004. Experimental studies on the formation of porous gas hydrates. American Mineralogist, 89, 1228 1239.

Gering, K.L., 2003. Simulations of methane hydrate phenomena over geologic timescales. Part I: Effect of sediment compaction rates on methane hydrate and free gas accumulations. Earth and Planetary Science Letters, 206, 65-81.

Gupta, A., Lachance, J., Sloan, E.D., Koh, C.A., 2008. Measurements of methane hydrate heat of dissociation using high pressure differential scanning calorimetry, Chemical Engineering Sciences, 63, 5848-5853, doi:10.1016/j.ces.2008.09.002.

Haacke, R., Westbrook, G.K., Riley, M.S., Controls on the formation and stability of gas hydrate-related bottom-simulating reflectors (BSRs): A case study from the west Svalbard continental slope. Journal of Geophysical Research, 113, B05104, doi:10.1029/2007JB005200, 2008.

Haeckel, M., Boudreau, B.P., Wallmann, K., 2007. Bubble-induced porewater mixing: A 3-D model for deep porewater irrigation. Geochimica et Cosmochimica Acta, 71, 51355154.

Haese, R.R., Meile, C., van Capellen, P., de Lange, G.J.. 2003. Carbon geochemistry of cold seeps: Methane fluxes and transformation in sediments from Kazan mud volcano, eastern Mediterranean Sea. Earth and Planetary Science Letters, 212: 361-375.

He, L., Matsubayashi, O., Lei, X., 2006. Methane hydrate accumulation model for the Central Nankai accretionary prism. Marine Geology, 227, $201-214$.

Heeschen, K.U., Collier, R.W., de Angelis, M.A., Suess E., 2005. Methane sources, distributions, and fluxes from cold vent sites at Hydrate Ridge, Cascadia Margin. Global Biogeochem. Cycles, 19, GB2016, doi:10.1029/2004GB002266.

Helbæk, M., Hafskjold, B., Dysthe, D.K., Sørland, G. H., 1996. Self-Diffusion Coefficients of Methane or Ethane Mixtures with Hydrocarbons at High Pressure by NMR. Journal of Chemical Engineering Data, 41, 598-603. 
Henry, P., Thomas, M., Clennell, M.B., 1999. Formation of natural gas hydrates in marine sediments, 2, Thermodynamic calculations of stability conditions in porous sediments. Journal of Geophysical Research, 104:2300523022.

Hensen, C., Zabel, M., Pfeifer, K., Schwenk, T., Kasten, S., Riedinger, N., Schulz, H.D., Boettius, A., 2003. Control of sulfate pore-water profiles by sedimentary events and the significance of anaerobic oxidation of methane for the burial of sulfur in marine sediments. Geochimica et Cosmochimica Acta, 67, 2631-2647.

Hughes, T.J.R., Masud A., Wan, J., 2006. A stabilized mixed discontinuous Galerkin method for Darcy flow. Computer Methods in Applied Mechanics and Engeniring, 195, 33473381.

Iverson N., Jorgensen, B.B., 1993. Diffusion Coefficients of Sulfate and Methane in Marine Sediments: Influence of porosity. Geochimica et Cosmochimica Acta, 57:571:578

Jørgensen, B.B., Weber, A., Zopfi, J., 2001. Sulfate reduction and anaerobic methane oxidation in Black Sea sediments. Deep-Sea Research Part. I, 48, 2097-2120.

Kim, H.C., Bishnoi, P.R., Heidemann, R.A., Rizvi, S.S.H., 1987. Kinetics of methane hydrate dissociation. Chemical Engineering Sciences, 56, 5801-5814.

Kimoto, S., Oka, F., Fushita, T., 2007. A chemo-thermo-mechanically coupled analysis of ground deformation induced by gas hydrate dissociation. International Journal of Mechanical Sciences, 52 (2010), 365-376.

Kowalsky, M.B., and Moridis, G.J., 2007. Comparison of Kinetic and Equilibrium Reaction Models in Simulating the Behavior of Gas Hydrates in Porous Media. Journal of Energy Conversion and Management, 48(6), 1850-1863, - doi: 10.1016/j.enconman.2007.01.017.

Kvenvolden, K.A., 1988. Methane hydrate: A major reservoir of carbon in the shallow geosphere, Chemical Geology, 71, 1-3, 41-51.

Lin, S., Hsieh, W.-C., Lim, Y.-C., 2006. Methane migration and its influence on sulfate reduction I the Good Weather Ridge, South China Sea, continental margin sediments. Terrestrial Atmospheric and Oceanic Sciences:17(4), 832-902.

Luff, R., Wallmann, K., 2003. Fluid flow, methane fluxes, carbonate precipitation and biogeochemical turnover in gas hydrate-bearing sediments at Hydrate Ridge, Cascadia Margin: Numerical modeling and mass balances. Geochimica et Cosmochimica Acta, 67, 3403-3421.

Masud A., Hughes, T.J.R., 2002. A stabilized mixed finite element method for Darcy flow. Computer Methods in Applied Mechanical Engineering. 191, 4341-4370 
Moridis, G.J., Kowalsky, M., Pruess, K., 2007. Depressurization-Induced Gas Production From Class 1 Hydrate Deposits. SPE Journal of Reservoir Evaluation \& Engineering, $10(5), 458-481$.

Moridis, G.J., Collett, T.S., Boswell, R., Kurihara, M., Reagan, M.T., Koh, C., Sloan, E.D., 2009. Toward Production From Gas Hydrates: Current Status, Assessment of Resources, and Simulation-Based Evaluation of Technology and Potential. SPE Reservoir Evaluation \& Engineering, 12(5): 745-771 (doi: 10.2118/114163-PA).

Nakshatrala, K.B., Turner, D,Z., Hjelmstad, K,D, Masud, A., 2006. A stabilized mixed finite element method for Darcy flow based on a multiscale decomposition of the solution. Computer Methods in Applied Mechanics and Engineering, 195, 4036-4049.

Niemann, H., Duarte, J., Hensen, C., Omoregie, E., 2006. Microbial methane turnover at mud volcanoes of the Gulf of Cadiz. Geochimica et Cosmochimica Acta, 70, 5336-5355.

Niewohner, C., Hensen, C., Kasten, S., Zabel, M., Schulz, H.D., 1998. Deep sulfate reduction completely mediated by anaerobic methane oxidation in sediments of the upwelling area off Namibia. Geochimica et Cosmochimica Acta, 62, 455-464.

Raviart, P.A., Thomas, J.M., 1977. A mixed finite element method for second order elliptic problems, in: Math. Aspects of the F.E.M., No. 606 in Lecture Notes in Mathematics, Springer-Verlag, pp. 292-315.

Rempel, A.W., Buffett B.A., 1997. Formation and accumulation of gas hydrate in porous media. Journal of Geophysical Research 102(B4), 10151-10164.

Riedel, M., Collett, T.S., Malone, M.J., and the Expedition 311 Scientists, editors. Cascadia Margin Gas Hydrates, volume 311 of Proc. IODP, Expedition Reports, College Station, TX, 2006. Integrated Ocean Drilling Program.

Sachs, W., 1998. The diffusional transport of methane in liquid water: method and result of experimental investigation at elevated pressure. Journal of Petroleum Science and Engineering, 21, 153-164.

Shen L., Chen Z., 2007. Critical review of the impact of tortuosity on diffusion. Chemical Engineering Science:62(14):3748-3755.

Shpakov, V.P., Tse, J.S., Tulk, C.A., Kvamme, B., Belosludov, V.R., 1998. Elastic moduli calculation and instability in structure I methane clathrate hydrate, Chemical Physics Letters, 282(2), 107-114.

Sultan, N., Cochonat, P., Canals, M., Cattaneo, A., Dennielou, B., Haflidason, H., Laberg, J.S., Long, D., Mienert, J., Trincardi, F., Urgeles, R., Vorren, T., Wilson, C., 2004. 
Triggering mechanisms of slope instability processes and sediment failures on continental margins: a geotechnical approach. Marine Geology, 213, 291-321.

Sun, R., Duan, Z., 2007. An accurate model to predict thermodynamic stability of methane hydrate and methane solubility in marine environments. Geochemical Geology; doi:10.1016/j.chemgeo.2007.06.021.

Sun, X.F. Mohanty, K.K., 2006. Kinetic simulation of methane hydrate formation and dissociation in porous media. Chemical Engineering Science, 61(11), 3476-3495.

Tishchenko, P., Hensen, C., Wallmann, K., Wong, C-S., 2005. Calculation of the stability and solubility of methane hydrate in seawater. Chemical Geology, 219, 37-52.

Tréhu, A.M., Ruppel, C., Holland, M., Dickens, G.R., Torres, M.E., Collett, T.S. , Goldberg, D., Riedel, M., Schultheiss P., 2006. Gas hydrates in marine sediments: lessons from scientific drilling. Oceanography, 19, 4, 124-142.

Treude, T., Niggemann, J., Kallmeyer, J., Wintersteller, P., Schubert, C.J., Boetius, A., Jorgensen, B.B., 2005. Anaerobic oxidation of methane and sulfate reduction along the Chilean continental margin. Geochimica et Cosmochimica Acta, 69, 2767-2779.

Xu, W.Y., Ruppel, C., 1999. Predicting the occurrence, distribution, and evolution of methane gas hydrate in porous marine sediments. Journal of Geophysical Research, 104, 50815095

Waite, W.F, Stern, L,A., Kirby S.H., Winters W.J., Mason, D.H., 2007. Simultaneous determination of thermal diffusivity and specific heat in sI methane hydrate. Geophysical. Journal International, 169, 767-774.

Waite, W. F., Santamarina, J. C., Cortes, D. D., Dugan, B., Espinoza, D. N., Germaine, J., Jang, J., Jung, J. W., Kneafsey, T. J., Shin, H., Soga, K., Winters, W. J., Yun, T.-S., 2009. Physical properties of hydrate bearing sediments. Reviews of Geophysics, 47, RG4003, doi:10.1029/2008RG000279.

Weast, R.C., 1987. CRC Handbook of Chemistry and Physics. CRC Press, Inc., Boca Raton. Wilder, J.W., Moridis, G.J., Wilson, S.J., Kurihara, M., White, M.D., Masuda, Y., Anderson, B.J., 2008. An international effort to compare gas hydrate reservoir simulators. In: Proceedings of the 6th International Conference on Gas Hydrates (ICGH 2008), Vancouver, British Columbia, Canada, July 6-10, 2008.December 2004; 213(1-4) : 291-321 doi/10.1016/j.margeo.2004.10.011

Zabaras, N., Samanta, D., 2004. A stabilized volume-averaging finite element method for flow in porous media and binary alloy solidification processes. International Journal for Numerical Methods in Engineering, 60/5, 1-38 


\section{Tables}

Table 1. Estimated methane fluxes at cold vent sites in literature.

\begin{tabular}{|l|l|l|}
\hline $\begin{array}{l}\text { Site } \\
\text { Bush Hill mount }\end{array}$ & $\begin{array}{l}\text { Methane Flux }\left(\mathrm{kg} / \mathrm{m}^{2} / \mathrm{s}\right) \\
\text { Nankai Trough }\end{array}$ & $\begin{array}{l}\text { Reference } \\
\text { Chen and Cathles, } 2005\end{array}$ \\
\hline Hydrate Ridge & $9.1 \times 10^{-7}$ & He et al., 2006 \\
\hline Gulf of Mexico & $2.7 \times 10^{-11}-3.7 \times 10^{-10}$ & Heeschen et al., 2005 \\
\hline Gulf of Cadiz & $1.0 \times 10^{-11}-3.9 \times 10^{-11}$ & Niemann et al., 2006 \\
\hline Namibian continental slope & $1.2 \times 10^{-11}-2.6 \times 10^{-11}$ & Niewöhner et al., 1998 \\
\hline Chilean shelf & $1.3 \times 10^{-11}-2.4 \times 10^{-11}$ & Treude et al., 2005 \\
\hline North-western Black Sea & $8 \times 10^{-12}-2 \times 10^{-11}$ & Jørgensen et al., 2001 \\
\hline Sea of Okhotsk & $2.8 \times 10^{-12}$ & Haeckel et al., 2007 \\
\hline Western Argentinean basin & $5 \times 10^{-13}$ & Hensen et al., 2003 \\
\hline
\end{tabular}




\section{Figures}

Figure 1. Methane solubility in grams of methane per kilogram of pore fluid versus pressure and temperature. The methane hydrate phase boundary (BGHSZ) separates the 2-phase $\mathrm{L}+\mathrm{G}$ (water and gas) and the 3-phase $\mathrm{L}+\mathrm{G}+\mathrm{H}$ (water, gas and hydrate) behaviors. (a) Diamonds mark the 2-phase solubility for $3.5 \mathrm{wt} \%$ salt ions (Duan and Mao, 2006); Triangles mark the 3-phase solubility for $\mathrm{S}=35$ while upside-down triangles mark the 3-phase solubility for 19 ppt of $\mathrm{Cl}$ (Tishchenko et al., 2005), and a thin dashed line marks the 2-phase solubility at atmospheric pressure. (b). Discontinuity of the 2-phase and 3-phase formal solubility at 20 $\mathrm{MPa}$ for 3.95 wt\% salt ions (Duan and Mao, 2006) and $\mathrm{S}=32$ as well as $\mathrm{Cl}=19 \mathrm{ppt}$ (Tishchenko et al., 2005).
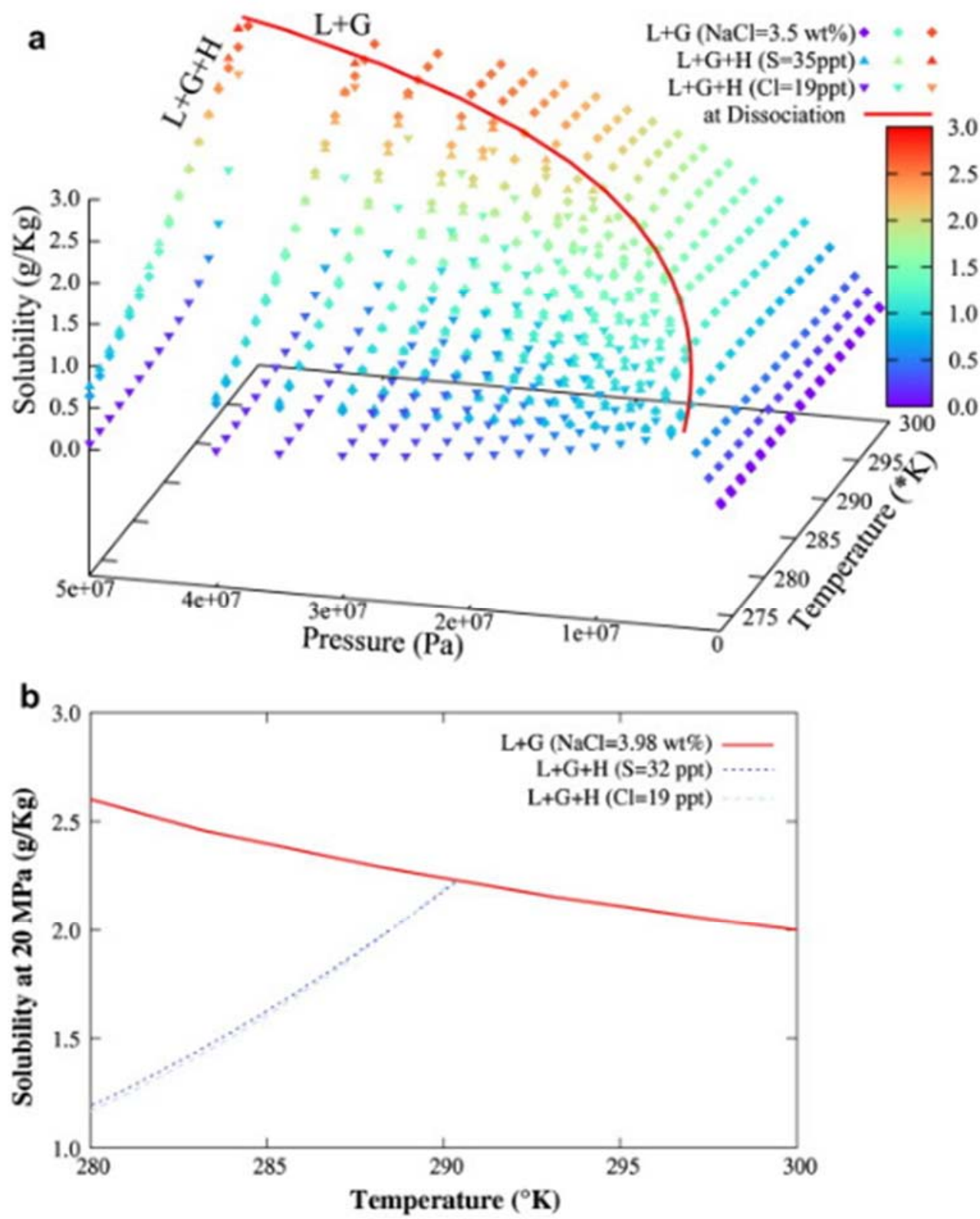
Figure 2. Initial temperature field, fixed at $275^{\circ} \mathrm{K}$ and with a $55 \mathrm{~mW} / \mathrm{m} 2$ basal heat flux and no initial methane.

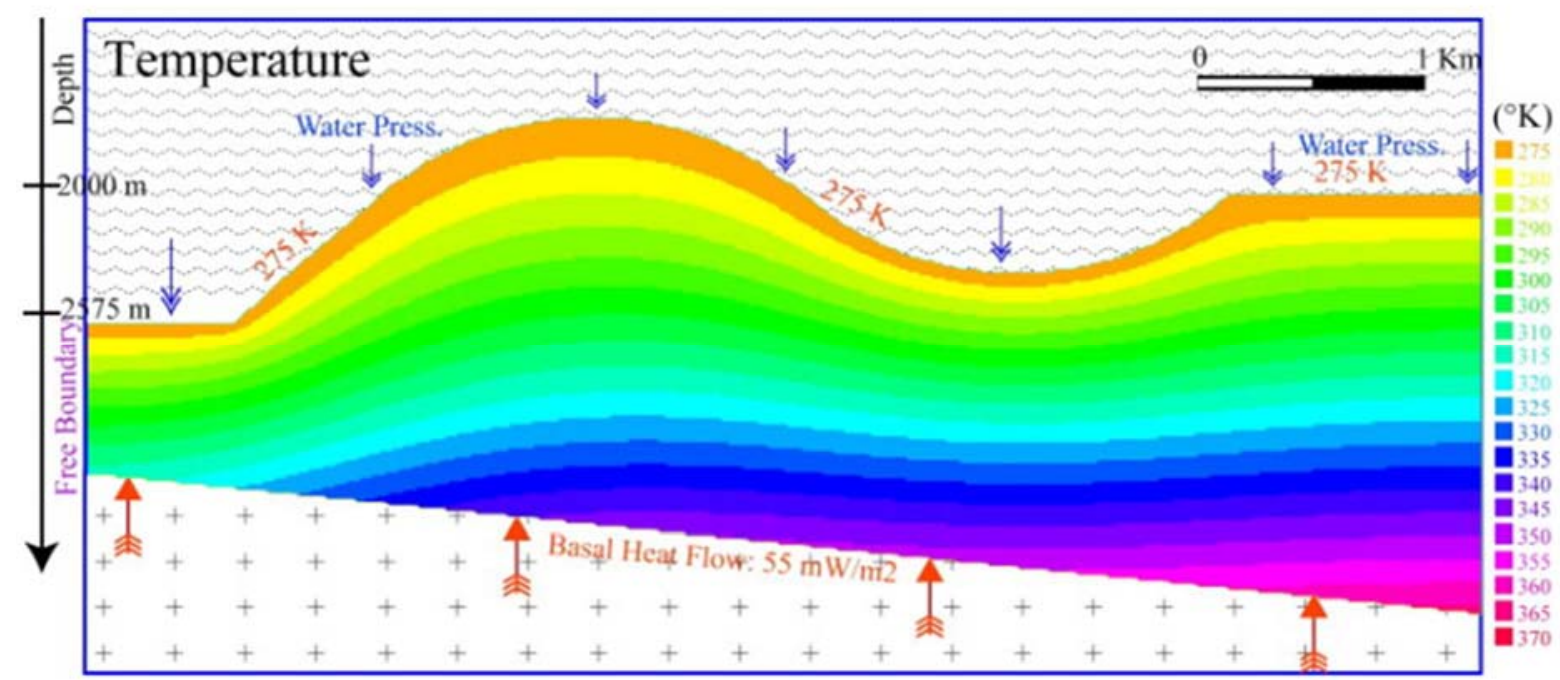

Figure 3. Free methane density from the vapor pressure predictions for supercritical gases of the modified Pengï Robinson equation of state (Gasem et al.; 2001). The buoyancy of free methane is minimal in the slope basin and maximal at the crest of the anticline.

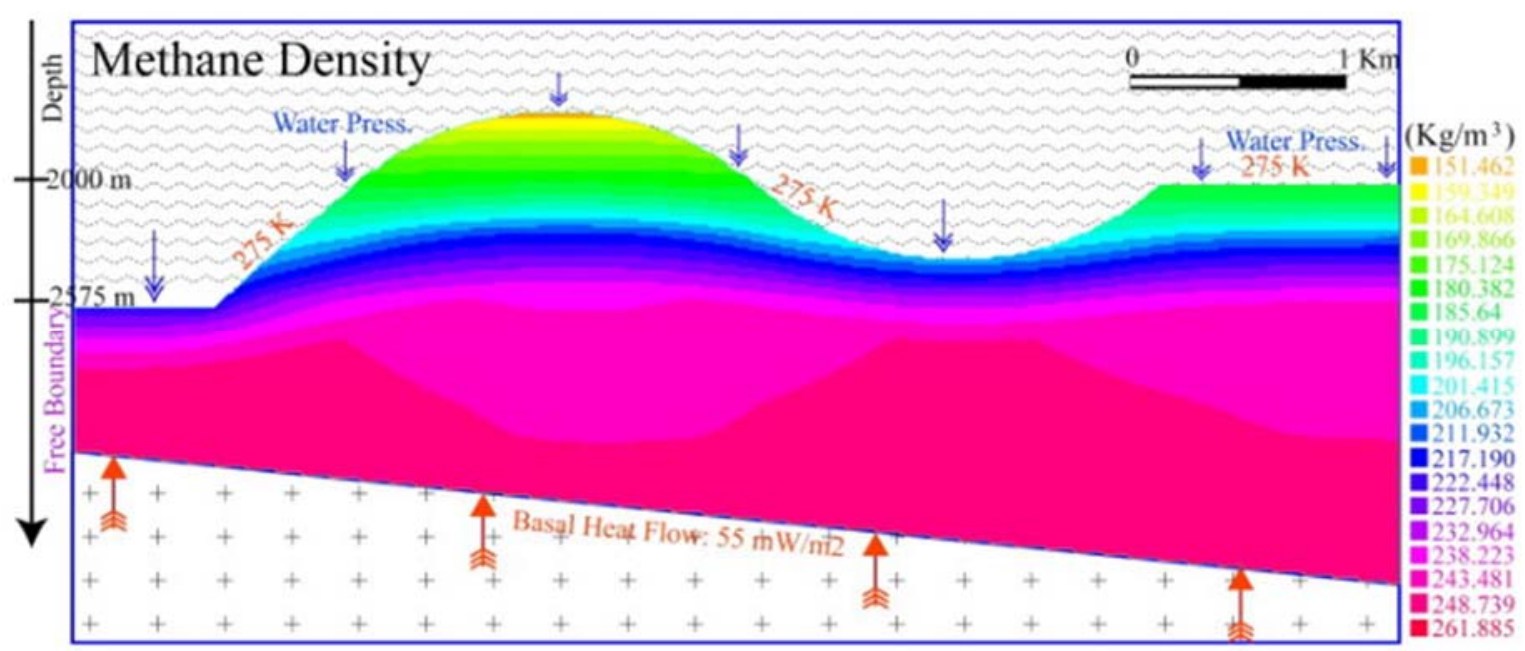


Figure 4. Methane solubility in the initial pressure and temperature conditions with $3.9 \mathrm{wt} \%$ salt ions and $19 \mathrm{ppt}$ chlorine. These amounts of dissolved methane (if converted to free gas) are equivalent to $0.8 \%$ of pore volume along all BGHSZ and $0.6 \%$ at the base of the model.

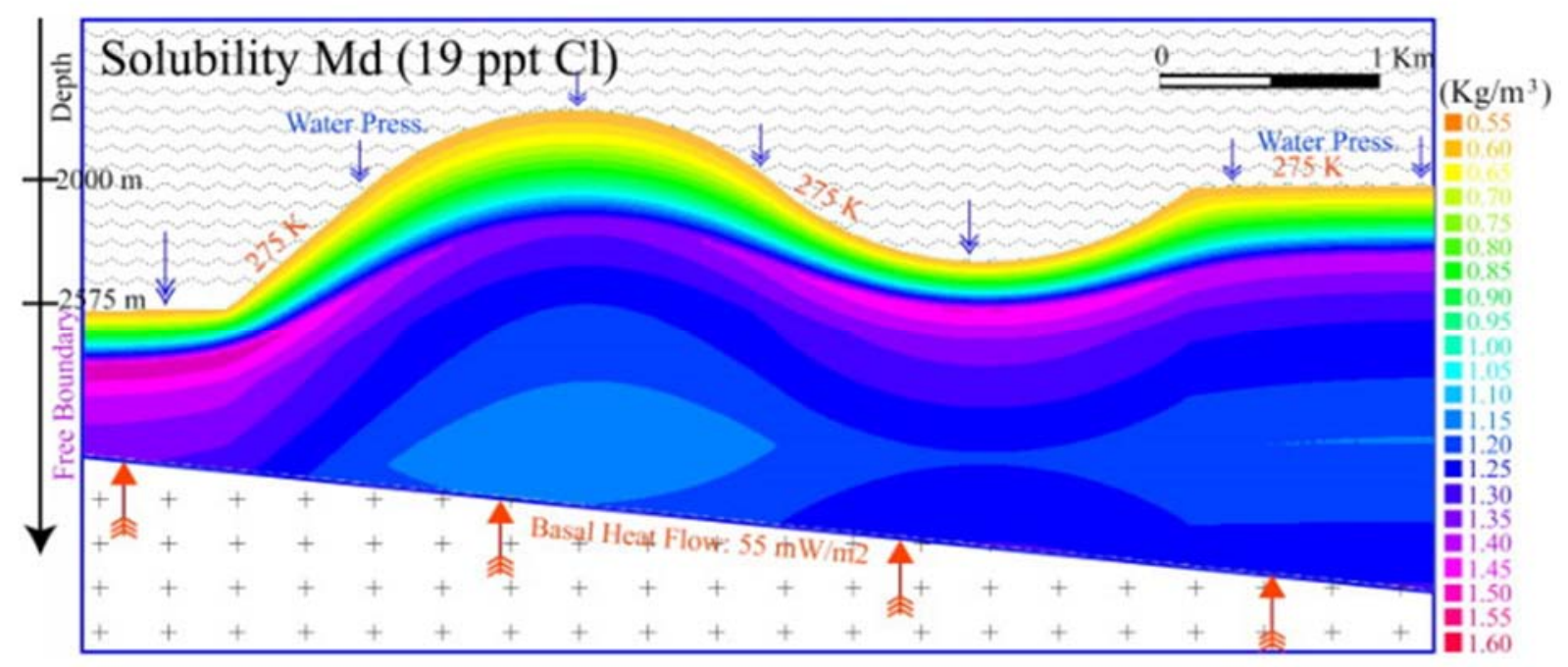

Figure 5. Intrinsic dissolved methane flux resulting from the solubility gradient at full dissolution, in the initial pressure and temperature conditions with $3.9 \mathrm{wt} \%$ salt ions and 19 ppt chlorine.

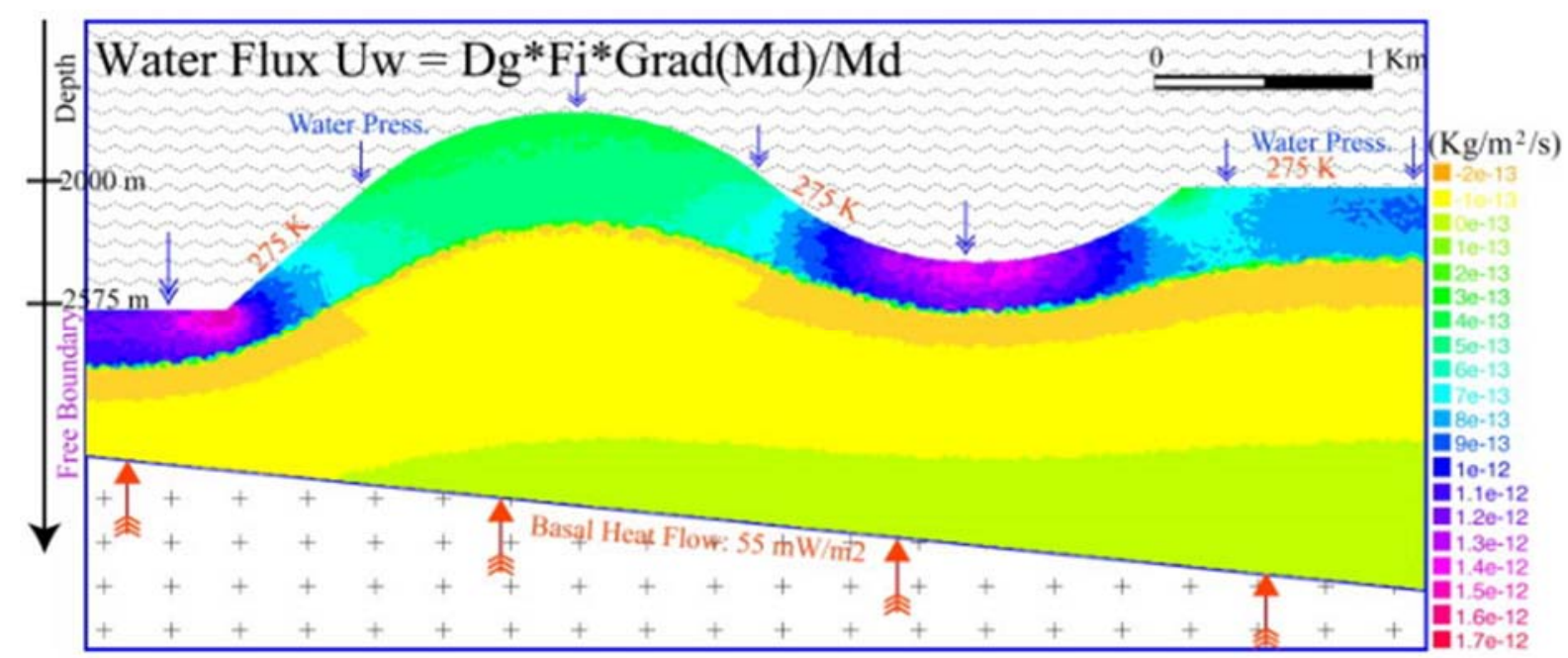


Figure 6. Methane budget for cases A in black, B in grey, and C in light grey. Gas hydrate and free methane grow steadily throughout the simulation, beginning shortly prior reaching full dissolution. Free gas budget is very similar in all models. In case of high water flux B, almost 7 kton of dissolved methane are carried across the top of the model, and 5.4 kton more hydrate form when compared to cases $\mathrm{A}$ and $\mathrm{C}$.

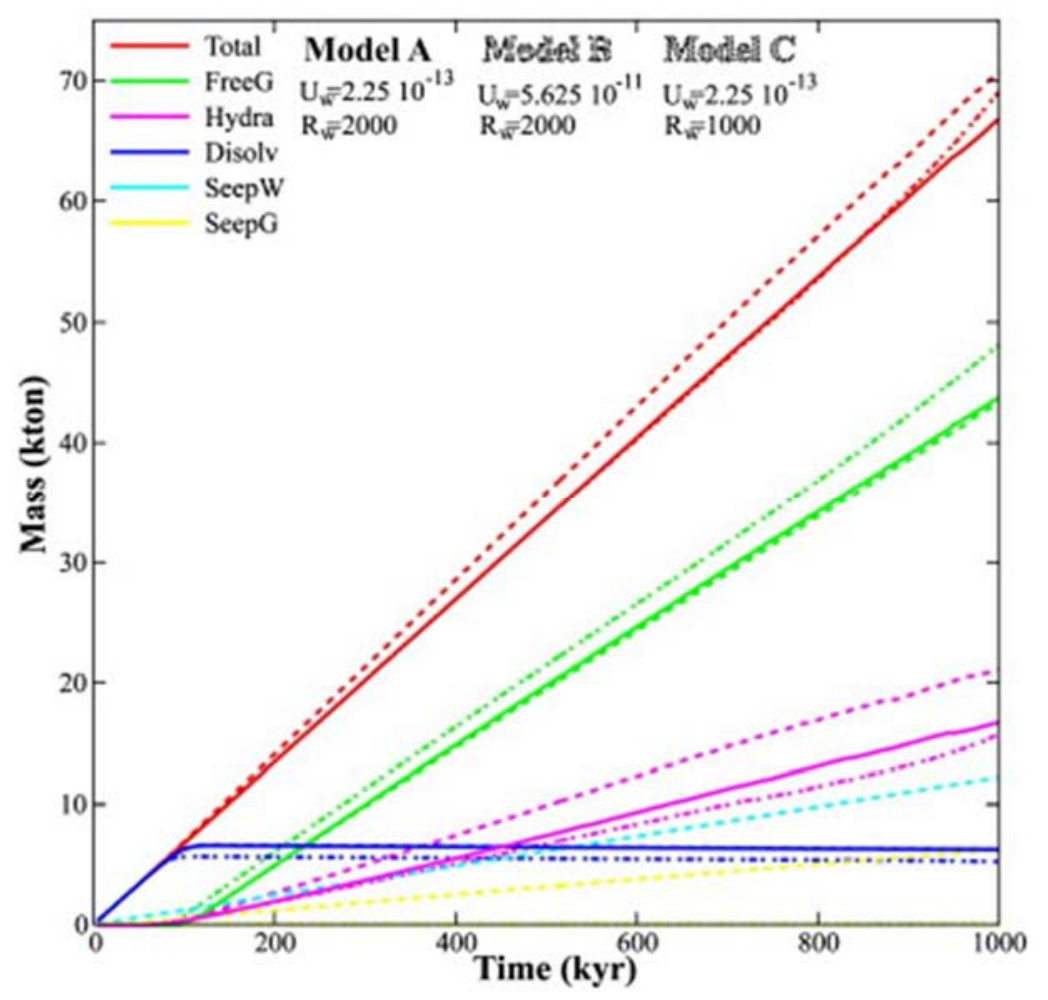


Figure 7. Free methane saturation reached after 1 Ma for cases (a) A and (b) B. Inherited by the solubility profile, free gas saturation is higher in the anticline. Although methane production rates are equal in both cases, a more pronounced methane front characterizes the BGHSZ in case A.
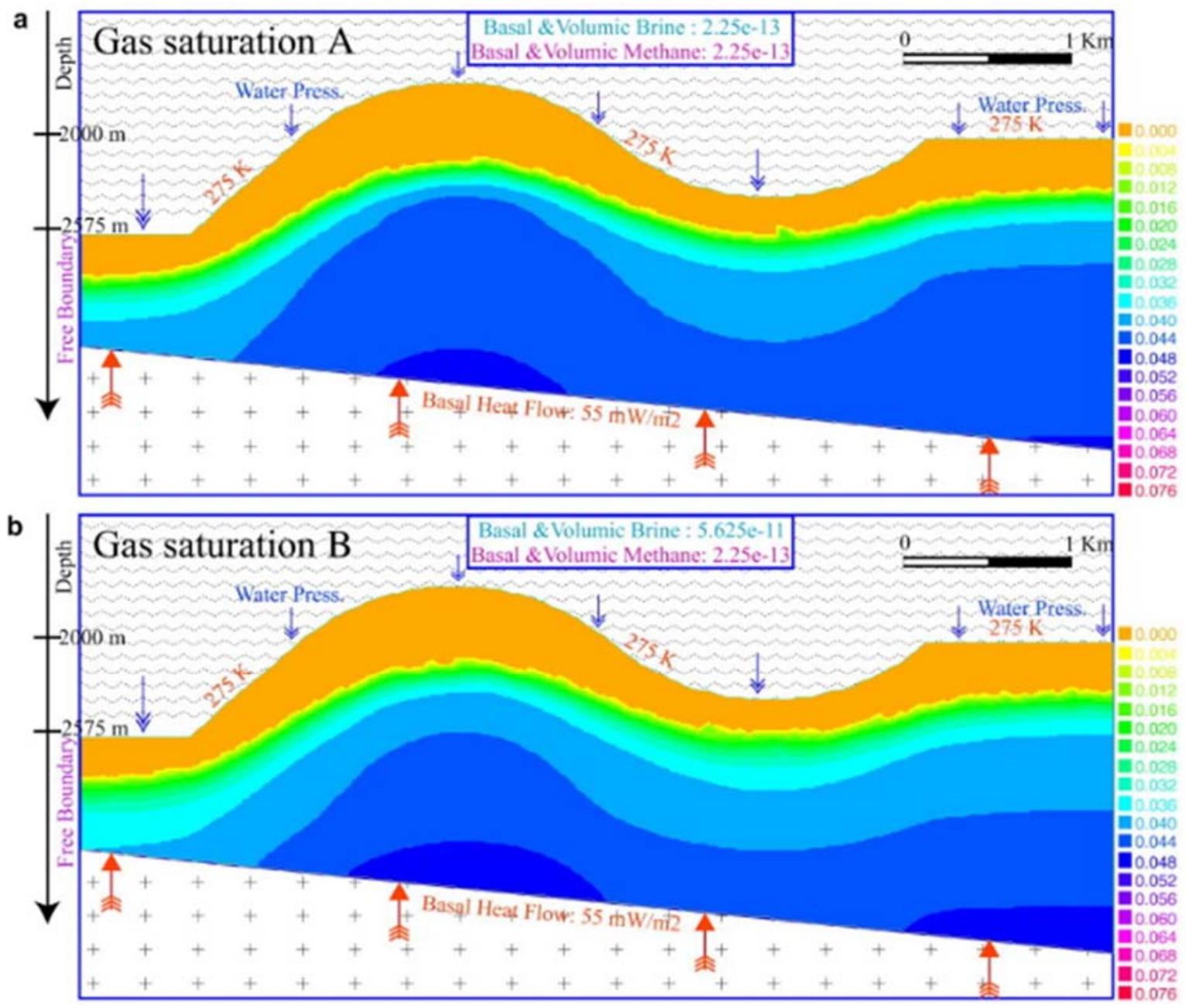
Figure 8. Methane hydrate saturation reached after $1 \mathrm{Ma}$ for cases (a) A and (b) B. Total hydrate emplaced for case B are $29 \%$ higher than for case A, but distribute comparatively between both cases. Along-strike variations are small at the BGHSZ, and more pronounced for case B, particularly when comparing anticline and slope basin.
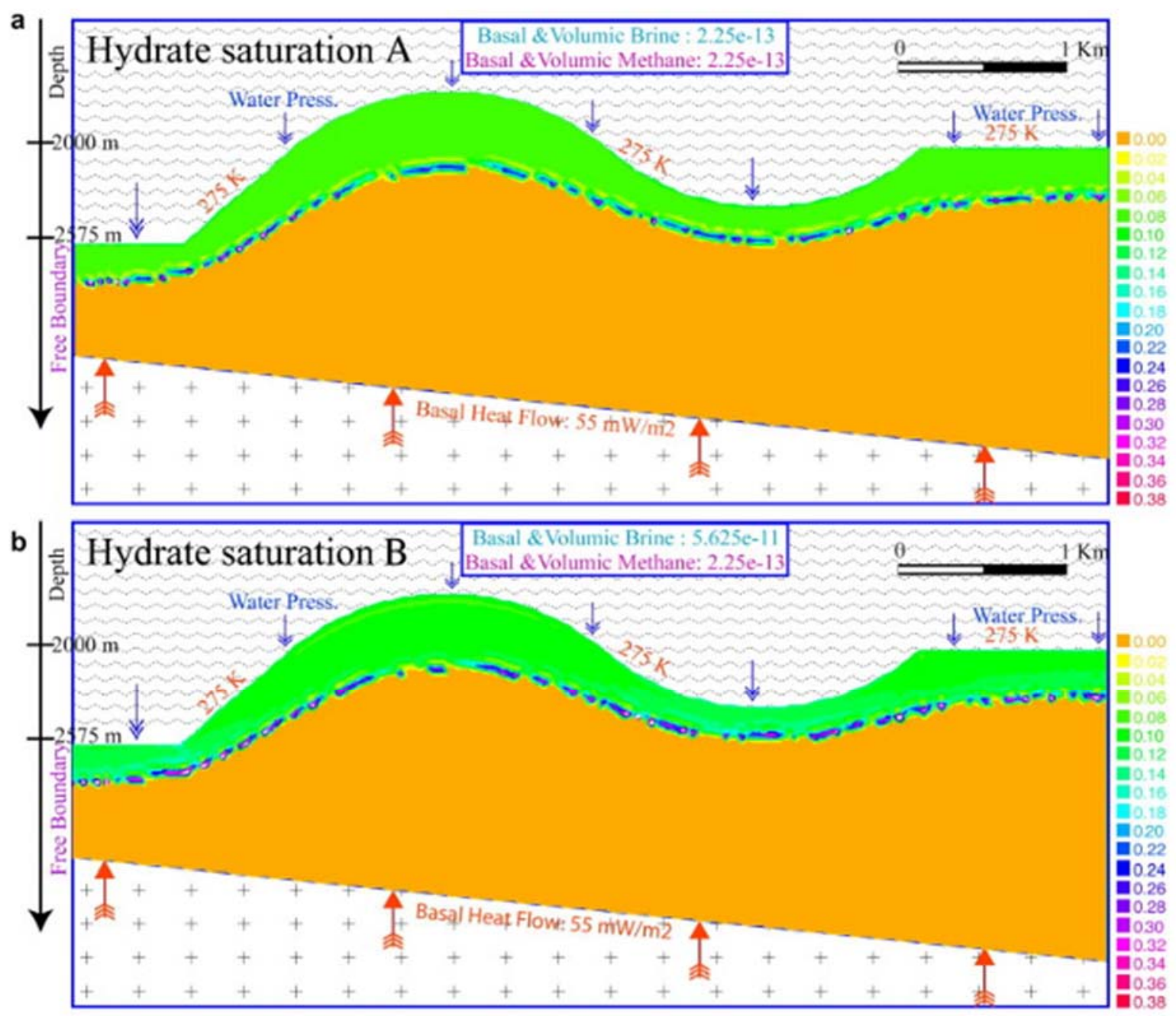
Figure 9. Hydrate and free methane saturation profiles for cases $A$ and $B$, at (a) the axis of the anticline $(x=3200)$ and (b) slope basin $(x=2230)$, with 25 kyr time steps. The vertical axis is scaled to the hydrate stability thickness (dimensionless). While higher saturations are emplaced in the slope basin than at the crest of the anticline for case B, similar profiles are observed for case A.
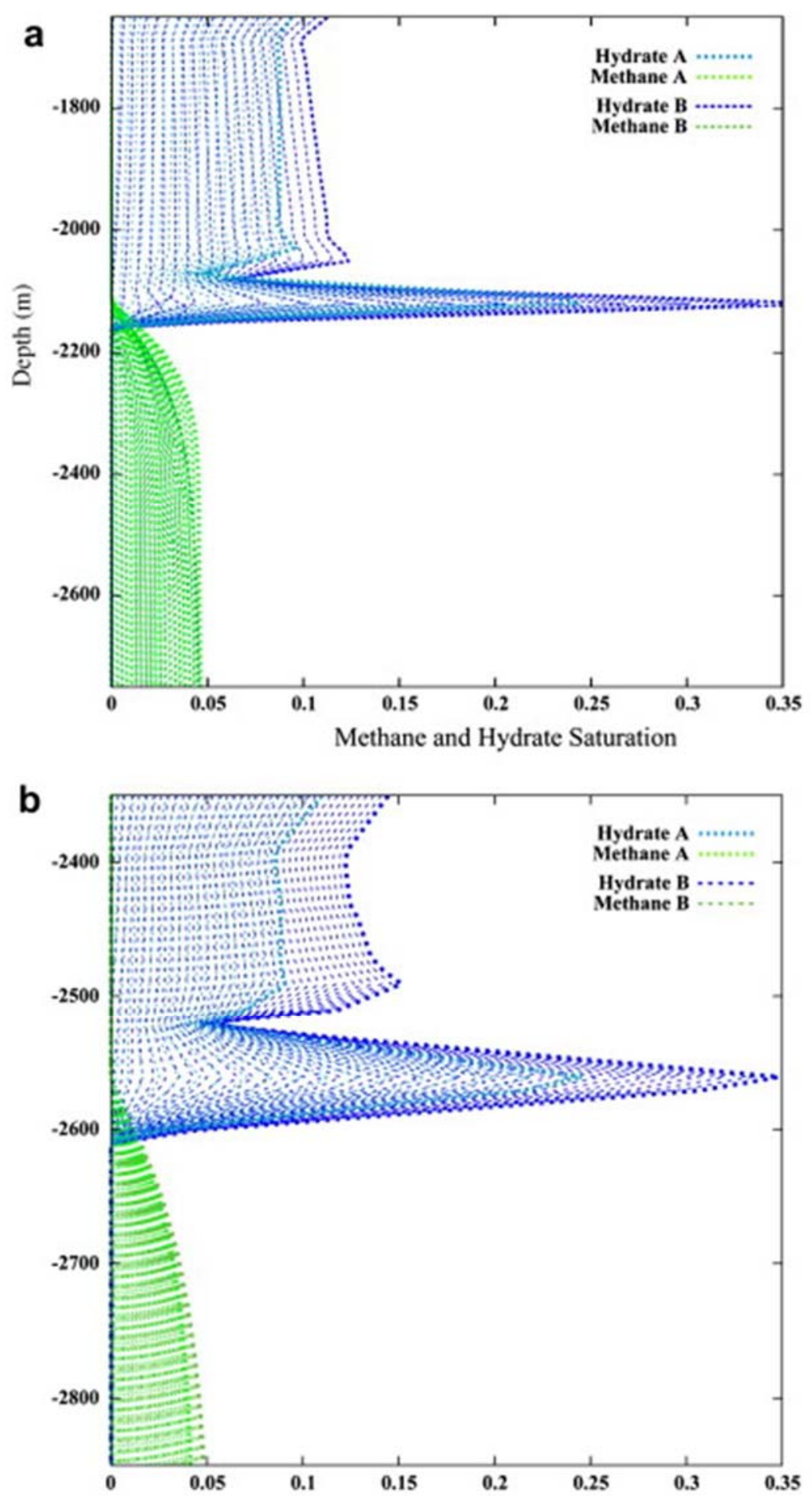
Figure 10. Hydrate and free methane flux for cases $A$ and $B$, at (a) the axis of the anticline $(\mathrm{x}=3200)$ and (b) slope basin ( $\mathrm{x}=2230)$, with $25 \mathrm{kyr}$ time steps. Pore-water flux hardly varies across profiles; Free gas flux remain close to the methane production rates for half of the simulation and increase considerably thereafter, as gas relative permeability increases with free methane saturation.
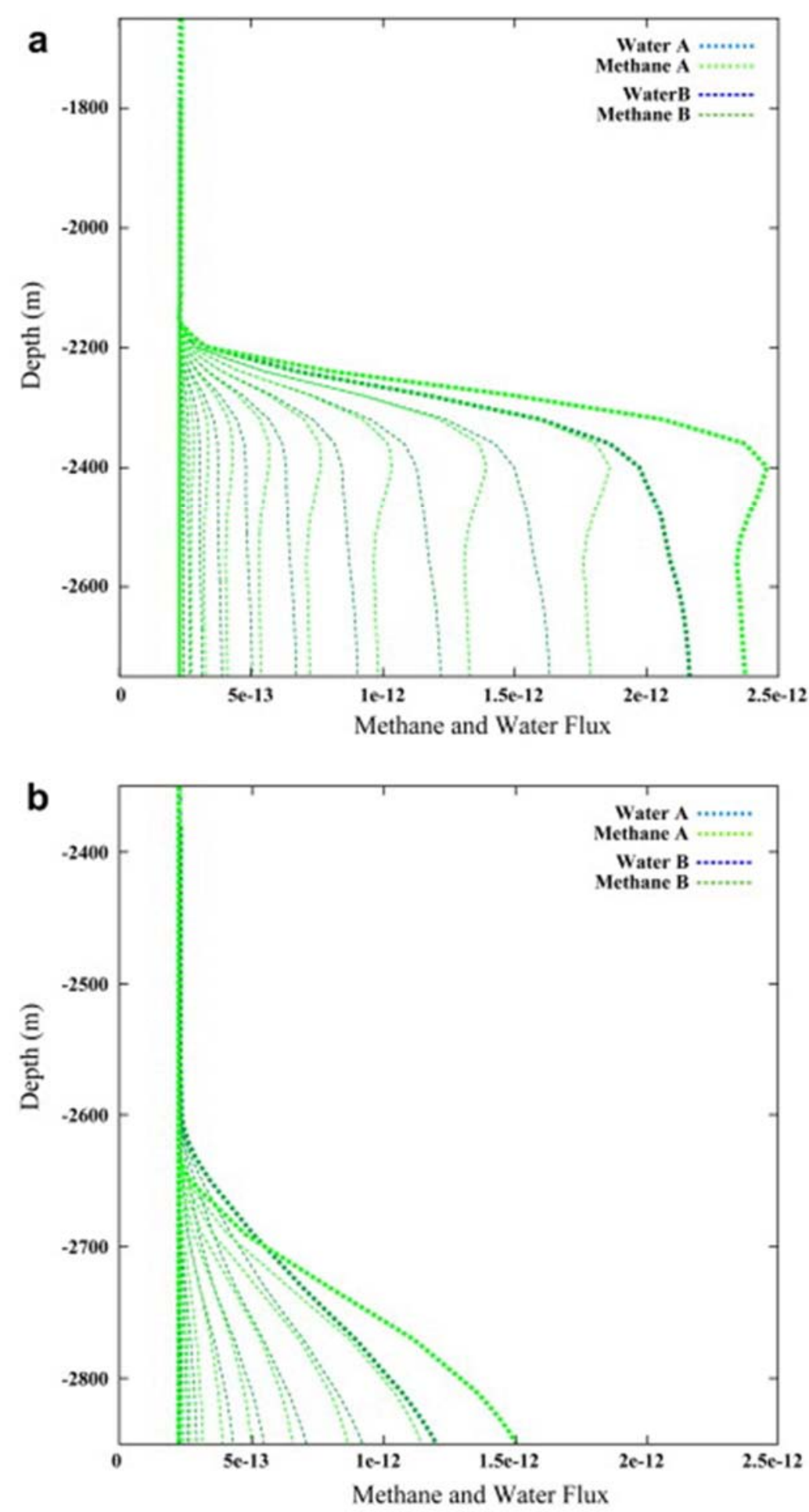
Figure 11. Hydrate and free methane saturation profiles for cases $A$ and $C$, at (a) the axis of the anticline $(x=3200)$ and (b) slope basin ( $x=2230)$, with $25 \mathrm{kyr}$ time steps. The vertical axis are stretched to equal GHSZ and plotted to the left and right for cases A and C, respectively. The two models are almost self-similar in the slope basin, when going from 2000 to $1000 \mathrm{~m}$ water depth and 55 to $45 \mathrm{~mW} / \mathrm{m} 2$ basal heat flux. Free methane buoyancy and solubility below the BGHSZ drive two very distinct hydrate saturation profiles at the crest of the anticline.
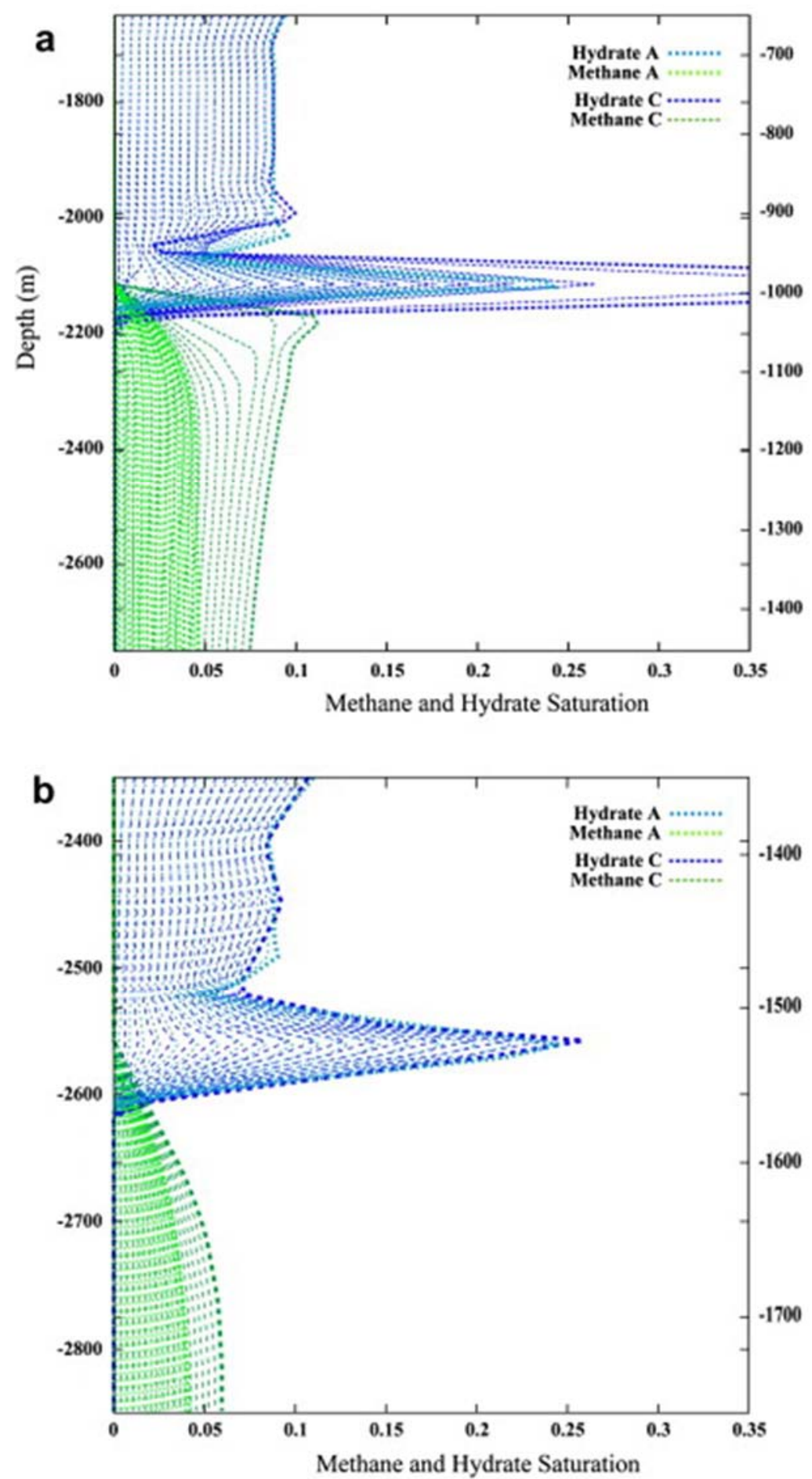